\title{
STRATIGRAPHIC AND STRUCTURAL INVESTIGATIONS IN THE IVISHAK RIVER AND GILEAD CREEK AREAS: PROGRESS DURING 2007
}

\author{
by \\ P.L. Decker ${ }^{1}$, M.A. Wartes ${ }^{2}$, W.K. Wallace ${ }^{3}$, D.W. Houseknecht ${ }^{4}$, \\ C.J. Schenk ${ }^{5}$, R.J. Gillis ${ }^{2}$, and J. Mongrain ${ }^{3}$
}

\begin{abstract}
Contractional deformation of foreland basin deposits adjacent to the northeast-southwest-trending mountain front in the east-central Brooks Range foothills exposes rock units of Albian to Late Cretaceous age that are largely concealed in the subsurface to the west and removed by erosion to the east. The informally named Gilead sandstone and overlying units in this area provide valuable insights into depositional systems active during the early and middle phases of foreland basin evolution, as well as an opportunity to study their responses to subsequent Brookian deformation. Systematic traverses of the Ivishak River, Gilead syncline, and Gilead Creek yield ubiquitous evidence of sediment gravity flow depositional processes in both the highly amalgamated sandstones and the intervening, finer-grained and thinner-bedded intervals throughout the Gilead sandstone, Seabee-equivalent strata, and the overlying Canning Formation. The amalgamated sandstone facies association of the Gilead succession contains many characteristics of hyperpycnal flow deposits, and submarine channels are locally preserved. Much of the unit may represent east- or northeast-flowing axial foredeep channel belt deposits. Sediment gravity flow sandstones in the upper parts of the Gilead unit that contain possible wave-influenced sedimentary structures may have been deposited south of the foredeep in shallower orogenic wedge-top, upper slope, or ramp settings. The Gilead sandstone has previously been interpreted to belong to a far-traveled allochthon, but we have found no compelling structural evidence to support this interpretation. Instead, observations appear consistent with lower Brookian strata at Gilead syncline forming the passive roof of a triangle zone duplex containing structurally thickened Valanginian and older strata. The Gilead sandstone itself is more strongly deformed on strike to the west at the Ivishak River. Transverse tear and rotational faults may account for the alongstrike compartmentalization of deformation. These preliminary interpretations require further scrutiny and the incorporation of pending analytical results from samples collected during these investigations.
\end{abstract}

\section{INTRODUCTION}

Reconnaissance during the 2007 field season addressed stratigraphic and structural uncertainties in the Ivishak River-Gilead Creek area (figs. 1-3) in preparation for detailed geologic mapping in this part of the Foothills belt during 2008 and subsequent years. These drainages are located on the northeast-southwest-trending edge of the northeastern Brooks Range salient where rocks of the lower and middle Brookian sequence that are restricted to the subsurface in most of the Foothills have been brought to the surface. This presents a unique opportunity to study the evolution of the foreland basin, and provides direct insight into the Foothills petroleum system in the adjacent subsurface.

An inherent challenge to understanding the Brookian foreland basin sequence is that the nomenclature, organization, thickness, depositional environments, and lithostratigraphy of the succession in any given area may be very different than the stratigraphic equivalents elsewhere in the basin (for example, Molenaar and others, 1986; Decker, 2007). The Ivishak River-Gilead Creek outcrop belt presents a conundrum analogous to trying to solve a system of equations with too many variables: the Brookian sequence differs dramatically from other areas, but because of obvious structural complications, the original stratigraphic succession has never been fully reconstructed. Conversely, the complete structural picture remains elusive, and thus difficult to filter out, because the original stratigraphy is not adequately understood.

\footnotetext{
${ }^{1}$ Alaska Division of Oil \& Gas, 550 W. 7th Ave., Suite 800, Anchorage, Alaska 99501-3560

Email for Paul L. Decker: paul.decker@alaska.gov

${ }^{2}$ Alaska Division of Geological \& Geophysical Surveys, 3354 College Rd., Fairbanks, Alaska 99709-3707

${ }^{3}$ University of Alaska, Department of Geology \& Geophysics, P.O. Box 757320, Fairbanks, Alaska 99775-7320

${ }^{4}$ U.S. Geological Survey, 956 National Center, Reston, Virginia 20192

${ }^{5}$ U.S. Geological Survey, Box 25046 Denver Federal Center, Denver, Colorado 80225
} 

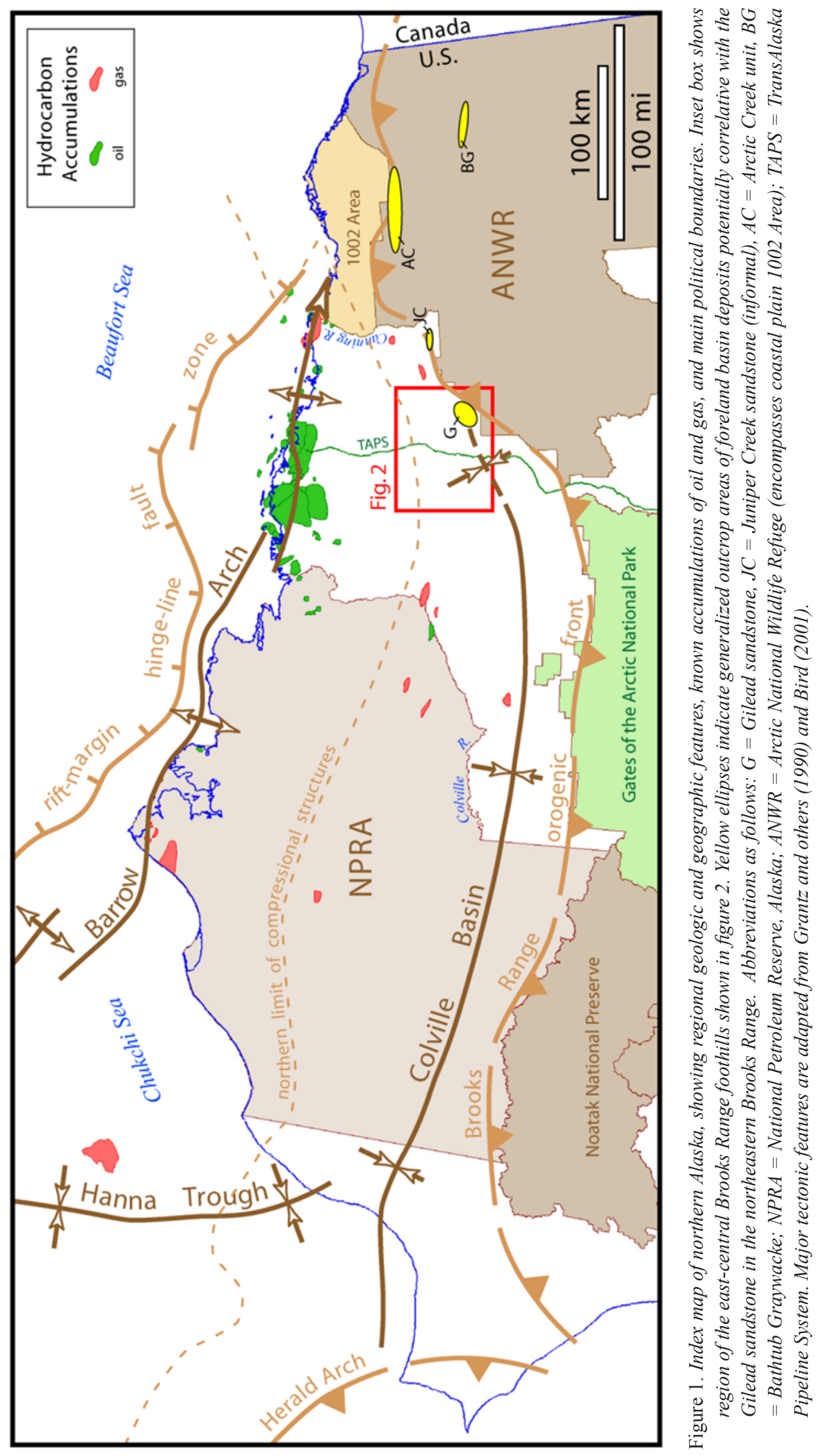


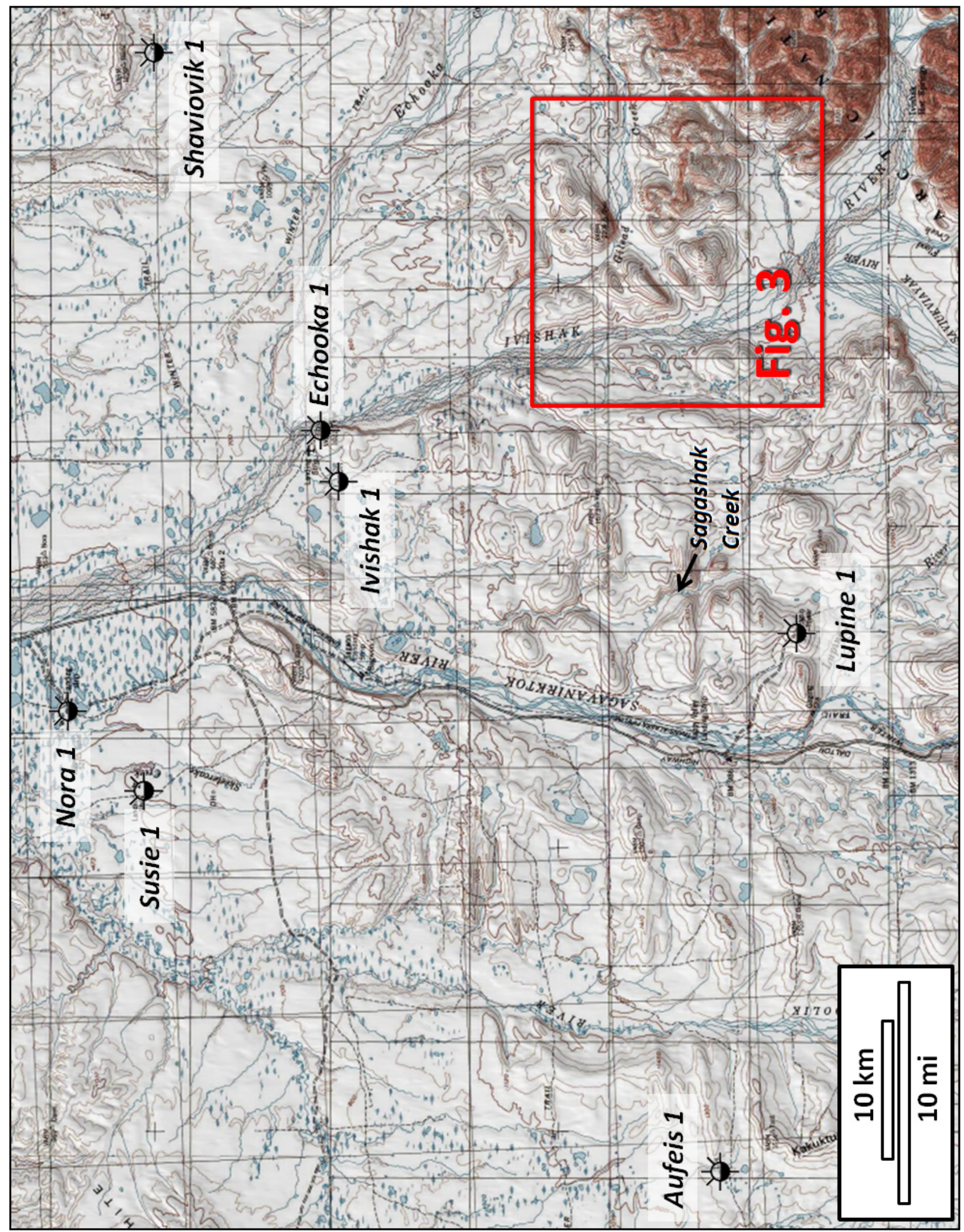

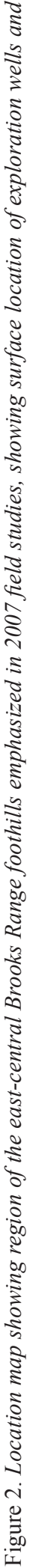

$\therefore \frac{\pi}{2}$

छ

$\stackrel{8}{8}$

क.

s

๑)

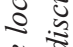

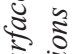

कर

है:

离

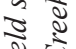

$\hat{\sigma}$

ป ن

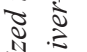

8

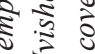

ปิ

8 5

5 ธิ

¿े है

के के

今े ซั

उ

บ

ป $\cong$

$\approx 2$

$0 \div$

के के

प

$\Rightarrow$ s.

के के

क

$\div$

5

రू

i

ะ ะ 
In their early mapping of the area, Keller and others (1961) assigned all Cretaceous rocks to the Ignek Formation. They differentiated two members mainly on the basis of pyroclastic content. They tentatively considered the units Lower and Upper Cretaceous in age, and speculated that they were separated by an unconformity. They viewed the lower member's siltstone, shale, and subgraywacke as partially equivalent to rocks now assigned to the Nanushuk and Torok Formations (fig. 4), and the upper member's pyroclastic (tuffaceous) shale and lesser sandstone and siltstone as partially equivalent to the Colville Group. The Ignek Formation was abandoned by Detterman and others (1975), and the encompassing term "Colville Group" was abandoned by Mull and others (2003). In the current formal nomenclature, Upper Cretaceous rocks of Keller and others' (1961) upper member would ideally be divided into the upper Hue Shale, Seabee, Canning, Schrader Bluff, and perhaps Prince Creek Formations (fig. 4). In the field, however, these units can be difficult to distinguish reliably because of structural complication and limited exposures that lack stratigraphic context. Much of the Lower to Upper Cretaceous section in the study area is dominated by deepwater turbidites and other sediment gravity flow deposits. Lithologically

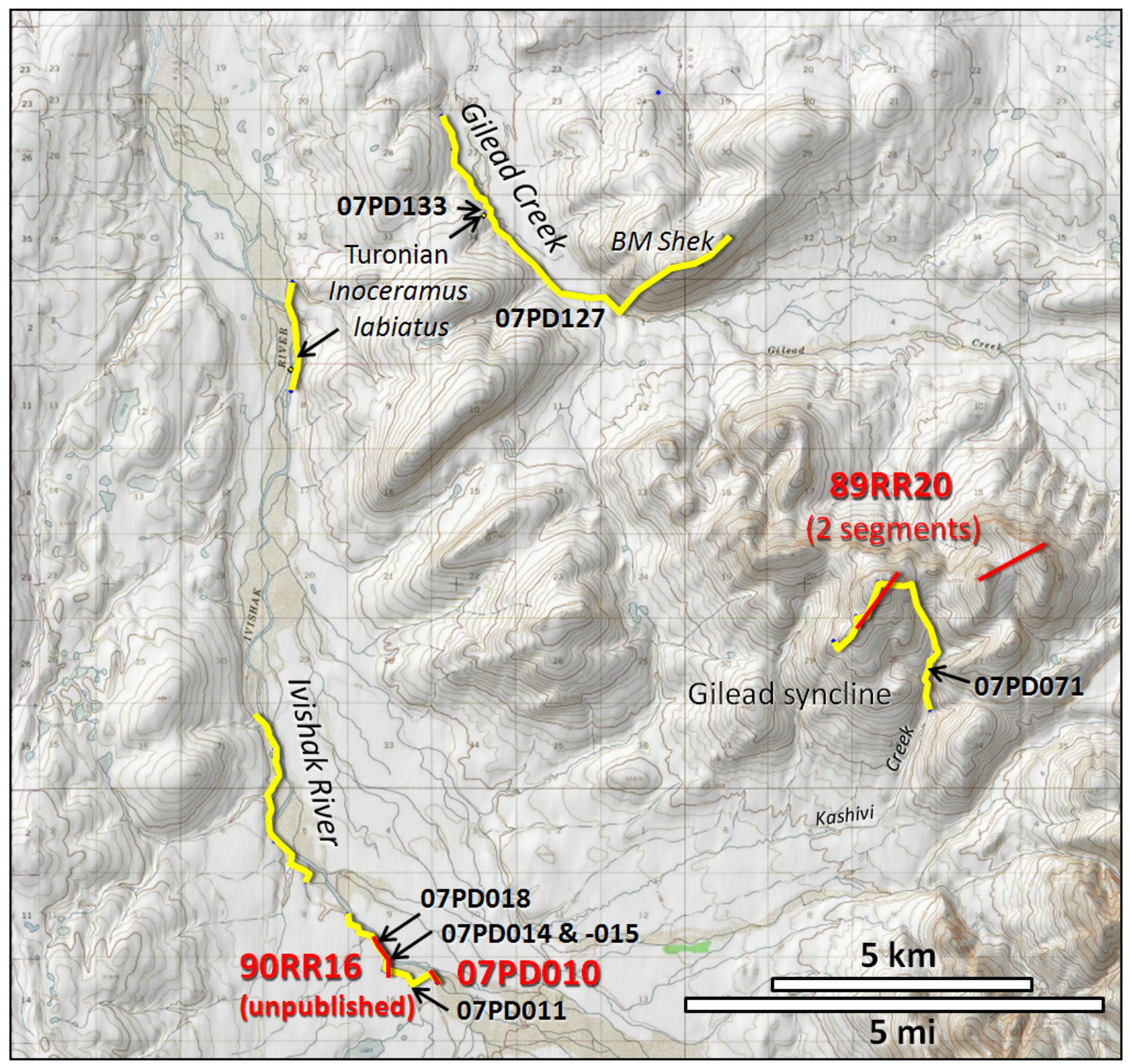

Figure 3. Location map showing detailed 2007 season foot traverses through Gilead sandstone and associated Upper Cretaceous rocks (yellow lines), measured sections of the Gilead sandstone (red lines and labels), including 2007 Ivishak River section 07PD010 (see Sheet F-1), Gilead syncline section 89RR20, and unpublished Ivishak River section 90RR16 (Reifenstuhl, 1989; 1991), and other locations referred to in text. Adapted from 1:63,360-scale USGS topographic coverage. 
distinct intervals are commonly either abruptly interleaved by complex structures or appear to change gradationally from one to another, without clear formation boundaries. There is an overall northward younging trend along these stream drainages, but thrusting and folding complicate this broader pattern.

Reifenstuhl (1989) applied the informal name "Gilead Creek sandstone," later shortened to "Gilead sandstone" (Reifenstuhl, 1991), to a clastic succession at least $850 \mathrm{~m}$ thick in the Gilead Creek-Ivishak River area (figs. 2 and 3 ) that he reported as Albian to Cenomanian in age. This informal unit encompasses much of the interval formerly assigned by Keller and others (1961) to the Ignek Formation lower member. The Gilead sandstone is problematic from a mapping standpoint because its upper contact with overlying strata has never been defined. The Gilead sandstone has also remained poorly understood from a genetic perspective, for several reasons. The age and sequence stratigraphic nature of the undefined upper contact are not well constrained. Additionally, opinions vary

Figure 4. Chronostratigraphic column for the Colville basin, northern Alaska, from Mull and others (2003). The informally named Gilead sandstone (not shown in figure) includes hundreds of meters of Albian-Cenomanian strata, and is thus at least partially age-equivalent to the Torok and Nanushuk Formations. However, as discussed in text, the Gilead unit's upper and lower contacts are poorly defined, both chronostratigraphically and lithostratigraphically. Depositional environment and paleobathymetric interpretations also remain uncertain for much of the unit, making it difficult to represent in this context. Refer to original figure (Mull and others, 2003, fig. 3) for additional explanation.

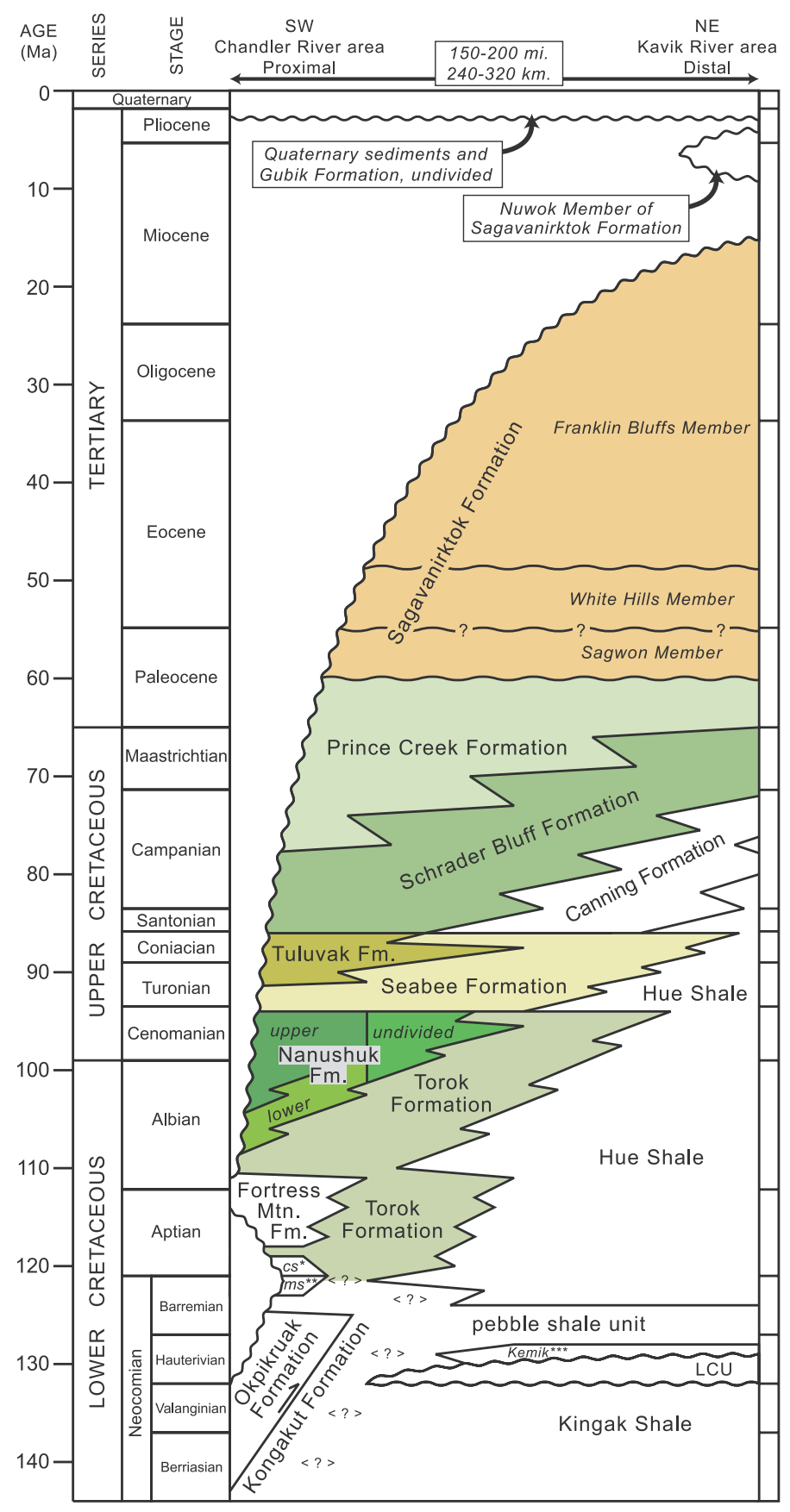


considerably regarding the range of water depths and depositional environments represented (Molenaar and others, 1984; Huffman and others, 1985; Pessel and others, 1990; Reifenstuhl, 1991; Schenk and Bird, 1993; LePain and Kirkham, 2002), making it difficult to interpret the paleogeographic setting of the Gilead sandstone within the foreland basin. Furthermore, there is almost certainly a detachment surface of some sort at the base of the Gilead sandstone at Gilead syncline (Reifenstuhl, 1989, 1991; Pessel and others, 1990), but it is uncertain whether the unit is essentially autochthonous (and thus, in its depositional context relative to the surrounding stratigraphic succession), or whether it is part of an allochthonous thrust or gravity-glide sheet that was transported from well to the south (for example, C.G. Mull, oral commun., 2007). The base of the sandy Albian-Cenomanian section at Gilead syncline is universally covered by rubble or vegetation, but it lies anomalously close to the deformed, underlying Kingak Shale. This leaves little room for the normal upper Beaufortian to lowermost Brookian stratigraphic succession of the North Slope autochthon and parautochthon (for example, Kemik Formation, pebble shale unit, and gamma-ray zone [GRZ] or basal Brookian mudstone). Finally, the Gilead unit is not present in coherent exposures of Neocomian through Upper Cretaceous stratigraphic strata just $19 \mathrm{~km}$ to the northeast on the Echooka River. These enduring enigmas are partly attributable to discontinuous frost-shattered exposures and structural dismemberment of the stratigraphic section. They highlight the need for better stratigraphic and structural models, constrained by detailed mapping that integrates additional field observations, refined age control, and petrographic study.

Our 2007 field investigations have not resolved these issues, but systematic foot traverses along the wellexposed reaches of the Ivishak River, Gilead Creek, and at Gilead syncline (fig. 3) generated numerous detailed observations that have already materially advanced our understanding of this complex area. This report discusses preliminary findings from field studies regarding the sedimentology, stratigraphy, and stacking architecture of the Gilead sandstone, and speculates on its depositional process and setting, and its relationship to overlying Upper Cretaceous rocks. It also documents key aspects of the structural geology that are crucial to predicting subsurface geometries and interpreting the basin evolution and hydrocarbon potential in this part of the North Slope Foothills. The descriptions, hypotheses, and tentative conclusions offered here are subject to change pending the results of ongoing analytical studies, future field investigations, and further refinement of interpretations.

\section{DESCRIPTION AND INTERPRETATION OF THE GILEAD SANDSTONE}

Reifenstuhl (1991) described the Gilead sandstone as "dominated by typically medium- to dark-gray, fine- to coarse-grained, subangular, moderately sorted litharenite, which weathers dark gray and orange-brown." We observe considerable variation in the color, composition, and texture of the unit, particularly in the upper portions. In hand specimens, the darker gray, compositionally and texturally immature sandstones are commonly described as graywacke or subgraywacke. The unit alternates between two major facies associations that tend to occur in discrete intervals tens of meters thick. As end members, these associations consist of either (1) medium- to massive-bedded (beds $10 \mathrm{~cm}$ to $>1 \mathrm{~m}$ thick) sandstone with very little interbedded siltstone and shale, or (2) very thin-bedded (beds $1-3 \mathrm{~cm}$ thick) to ripple-laminated mixtures of very fine sandstone, siltstone, and shale. The least structurally disrupted, and perhaps most complete section of the Gilead sandstone, is at Gilead syncline, where nearly $850 \mathrm{~m}$ of gently to moderately dipping sandstone, siltstone, lesser shale, and thick covered intervals were measured by Reifenstuhl $(1989,1991)$. Exposures of the unit on the Ivishak River extend over a distance of approximately 13 $\mathrm{km}$ from south to north, but are mainly steeply dipping to overturned, and the amount of structural repetition by folding and faulting is difficult to determine. We have not yet estimated the stratigraphic thickness represented there. An unpublished 254-m-thick section was measured previously on the Ivishak River (Reifenstuhl, 1991), but it clearly encompasses only a minor fraction of the structurally complex exposures along the Ivishak River, and represents an uncertain portion of the Gilead interval.

\section{Stratigraphy of the Ivishak River Transect}

Stratigraphic and structural measurements and observations were collected along three foot traverses with a combined length of $8.8 \mathrm{~km}$ that represent nearly all of the exposed bedrock on this stretch of the Ivishak River (fig. 3). We measured a $160 \mathrm{~m}$ section of what appears to be the lower part of the Gilead sandstone at the south end of this transect, making detailed observations on grain size, bed thickness, sedimentary structures, paleocurrent indicators, composition, and stacking patterns, and collecting samples for petrography, micropaleontology, porosity and permeability, fission track thermochronology, and detrital zircon geochronology. Analytical results for these samples are not yet available. The measured section extends northward from station 07PD010 on the west side of the river a short distance downstream of the Saviukviayak River confluence (figs. 2 and 3), where nearly vertical sandstone beds are well exposed on a low, current-scoured bench that rises just above river level (fig. 5a). 
A preliminary version of the measured section is presented in Sheet F-1 of this report, which will be supplemented with analytical data and interpretations as they become available.

The Gilead sandstone in this measured section is dominated by 40-50-m-thick intervals of resistant, well sorted, lower to upper very fine-grained sandstone with little interbedded siltstone or shale, alternating with 5-30-m-thick intervals of recessive cover and very fine-grained, thin-bedded sandstones and siltstones. Lower to upper fine-grained sandstone is common and medium grains are locally abundant in moderately to poorly sorted portions of some beds. Sandstone beds with overall medium grain size are rare at this location, though they are common in some other Gilead outcrops. Sandstones from the measured section weather mostly medium gray, with local rusty-weathering beds and lenses, and are medium to dark olive-gray on freshly broken surfaces. Petrographic thin sections from this location are not yet available, but the sandstones appear in hand specimen to consist of subrounded to angular quartz with abundant dark lithic fragments, and less than 5 percent yellow-orange limonitic fragments, consistent
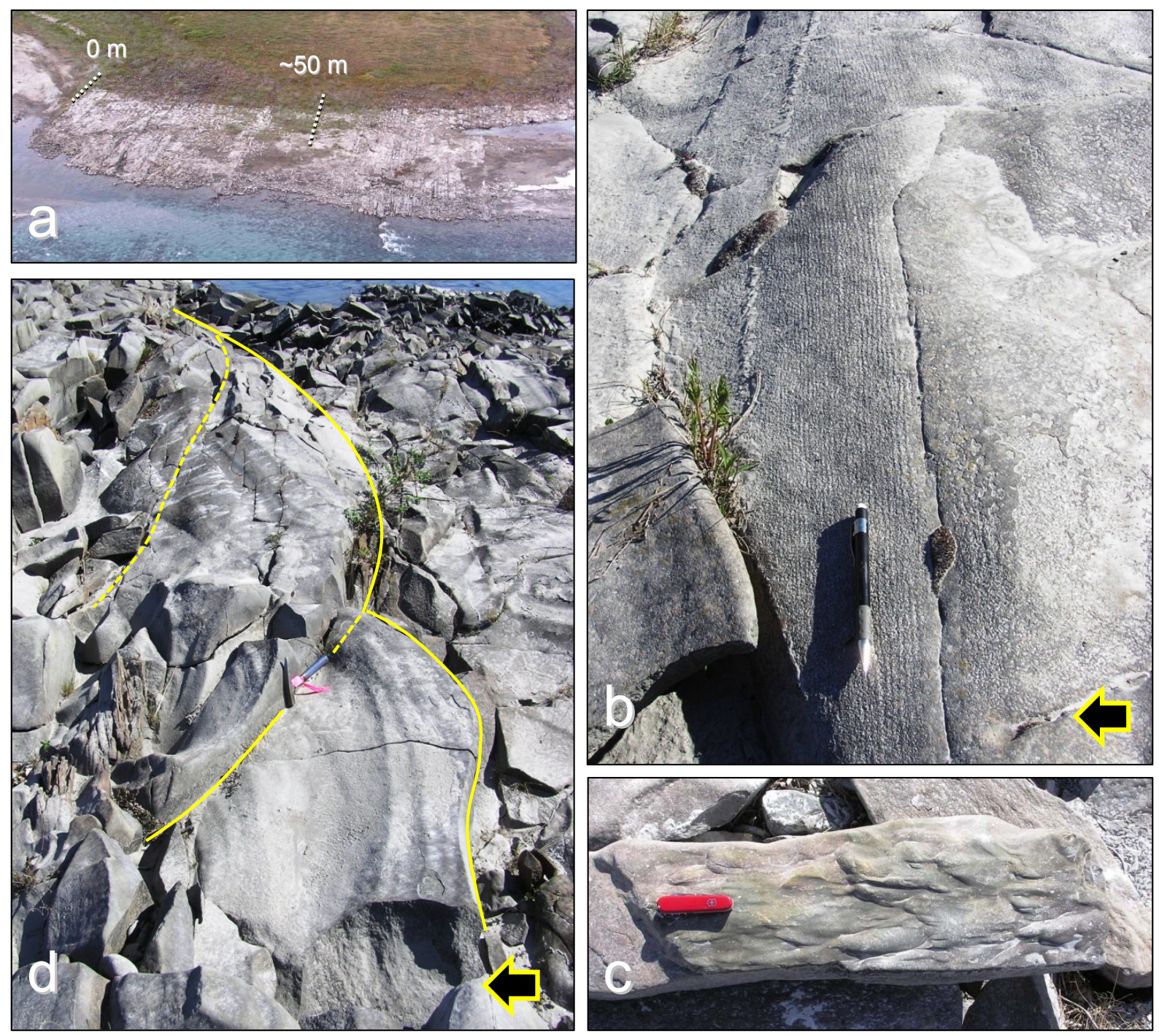

Figure 5. Photos of measured section of lower Gilead sandstone at station 07PD010 on the west bank of the Ivishak River (location labeled in fig. 3). (a) Aerial overview looking west-southwest at the lower two-thirds of the section. (b) Upper flow regime planar lamination is common, as in this example from approximately $8 \mathrm{~m}$ above the base of the measured section. Stratigraphic up direction is to left (north) as indicated by arrow. (c) Flute casts (in float at approximately $80 \mathrm{~m}$ in section) are uncommon in the measured section, though they occur occasionally throughout the Gilead sandstone. (d) Complex of large scale cut-and-fill structures with compound curviplanar and planar-laminated fill at approximately 10-12 $\mathrm{m}$ in section. Largest scours are nearly $1 \mathrm{~m}$ deep by $5 \mathrm{~m}$ wide. Stratigraphic up direction is to left (north) as indicated by arrow. 
with the litharenite designation applied to the Gilead sandstone by Reifenstuhl $(1989,1991)$. Metamorphic rock fragments, especially of micaceous phyllite(?) detritus, are locally abundant along the Ivishak River transect, and are most conspicuous in coarse to very coarse sandstone beds that crop out north of the measured section. The sandstones of this measured section are well indurated and appear silicified, suggesting paleo-burial at substantial depth corresponding to paleotemperatures exceeding $80-100^{\circ} \mathrm{C}$ (Worden and Burley, 2003). This is consistent with paleotemperatures $>110^{\circ} \mathrm{C}$ indicated by fission track analyses (O'Sullivan, 1991), and with vitrinite reflectance values in the 1.0-2.3 percent range (Reifenstuhl, 1991) reported from Gilead syncline.

As described and illustrated on Sheet F-1, Gilead sandstone beds are typically decimeters to more than a meter thick, commonly amalgamated from multiple flow events, and they contain current-generated sedimentary structures and other features associated with full or partial Bouma successions. Stratigraphic up direction is commonly indicated by an incredibly diverse suite of load casts developed at the base of many structureless or convolute-bedded (Ta) sandstone beds. Loads vary from millimeter to decimeter scale, and include a broad range of forms that can be described as rounded-bulbous, linear-parallel, curvilinear-radial, or puckered, and in some instances, appear to transition between flute-shaped loads and loaded flutes. Grooves and flutes (fig. 5c) are more common in other outcrops than in this measured section, and are valuable indicators of stratigraphic younging direction. Upper flow regime planar lamination ( $\mathrm{Tb}$ facies, fig. $5 \mathrm{~b}$ ) with common parting lineation normally overlies the basal massive or convolute sandstones, and locally grades upward into low-angle trough cross-stratification. The latter is typically preserved as rusty-weathering remnant lenses at gently curved scoured amalgamation surfaces between higher energy sands. Large scour-and-fill features, up to $1 \mathrm{~m}$ deep and $5 \mathrm{~m}$ wide, are locally abundant and nested, for example, from 10 to $13 \mathrm{~m}$ in the measured section (fig. 5d). These and other, more cryptic amalgamation surfaces locally modify the normal Bouma sequence. This has generated amalgamated sandstones with reversed or complicated stacking architectures, for example, Tab-a-abc, where hyphens represent amalgamation or the resumption of higher energy flow. In many instances, it is unclear whether the amalgamation reflects erosion of fine-grained material, or if the event frequency was high enough to prevent the accumulation of mudstone.

Packages of current-ripple-laminated (Tc) sandstone ranging from a few centimeters to a decimeter or more in thickness are present at the tops of numerous beds in the amalgamated sandstone facies. Similar ripple-laminated units account for nearly all of the thin-bedded sands in recessive-weathering intervals. Ripple asymmetry indicates predominant paleocurrent flow was to the east or northeast. Locally, these rippled caps are overlain by thinner beds of lower flow regime planar-laminated (Td) siltstone. True shale is rarely preserved as very thin hemipelagic drapes (Te facies) above the laminated siltstone and below the overlying unit. Bedforms generated by either fair weather or storm waves are absent entirely from the measured section, but they may be present farther north in the central traverse segment on the Ivishak River (fig. 3). Trace fossils are rare on the Ivishak River transect, restricted to isolated occurrences of nondescript Planolites on beds that also contain groove casts. This suggests the burrowing organisms may have been transported into the depositional environment by turbidity currents along with woody debris and other detritus.

In measured section 07PD010, the mostly amalgamated sandstone facies association is present in three main packages, and constitutes approximately 60 percent of the $160 \mathrm{~m}$ section; the thin-bedded to ripple-laminated finegrained association accounts for the other 40 percent. It is our impression that this ratio is fairly representative of the Gilead sandstone as a whole. Both upward-coarsening/thickening and upward-fining/thinning stacking patterns are observed, and in some instances, beds of highly variable thickness are developed with no discernable grain size or thickness trend, as shown in figure 6 from a sandy interval north of the measured section at station 07PD018. The bases of sand-rich cycles are either abrupt or gradational, but their tops are characteristically sharp.

Sandstone beds in some Gilead exposures reach thicknesses of several meters with only rare ripple-laminated partings to indicate episodes of lower energy flow between high energy depositional phases. An example is the 3.5 -m-thick bed shown in figure 6, consisting mostly of massive to faintly planar laminated sandstone with a single internal parting surface defined by ripple lamination. The upper $15-18 \mathrm{~cm}$ is current-ripple laminated to lower flow regime planar laminated sandy siltstone with abundant woody impressions. This anomalously thick sandstone bed is interpreted to record deposition from sustained, mainly high energy flow during a single major event, perhaps a large flood in the provenance area.

Where exposed, the recessive, thin-bedded and ripple-laminated facies association consists largely of rusty reddish brown- and iridescent purple-weathering lower very fine-grained sandstone, siltstone, and shale (fig. 7b). These are typically arranged in laminated to thin $(<1-10 \mathrm{~cm}$ thick), upward fining and thinning graded beds characteristic of classical turbidites. Some recessive intervals contain sporadic 1-5-mm-thick bentonite laminae. Ash beds and dispersed tuffaceous material became increasingly abundant in northern Alaska during Cenomanian time, which suggests these exposures may belong to the upper part of the Gilead succession. Intervals of highly 

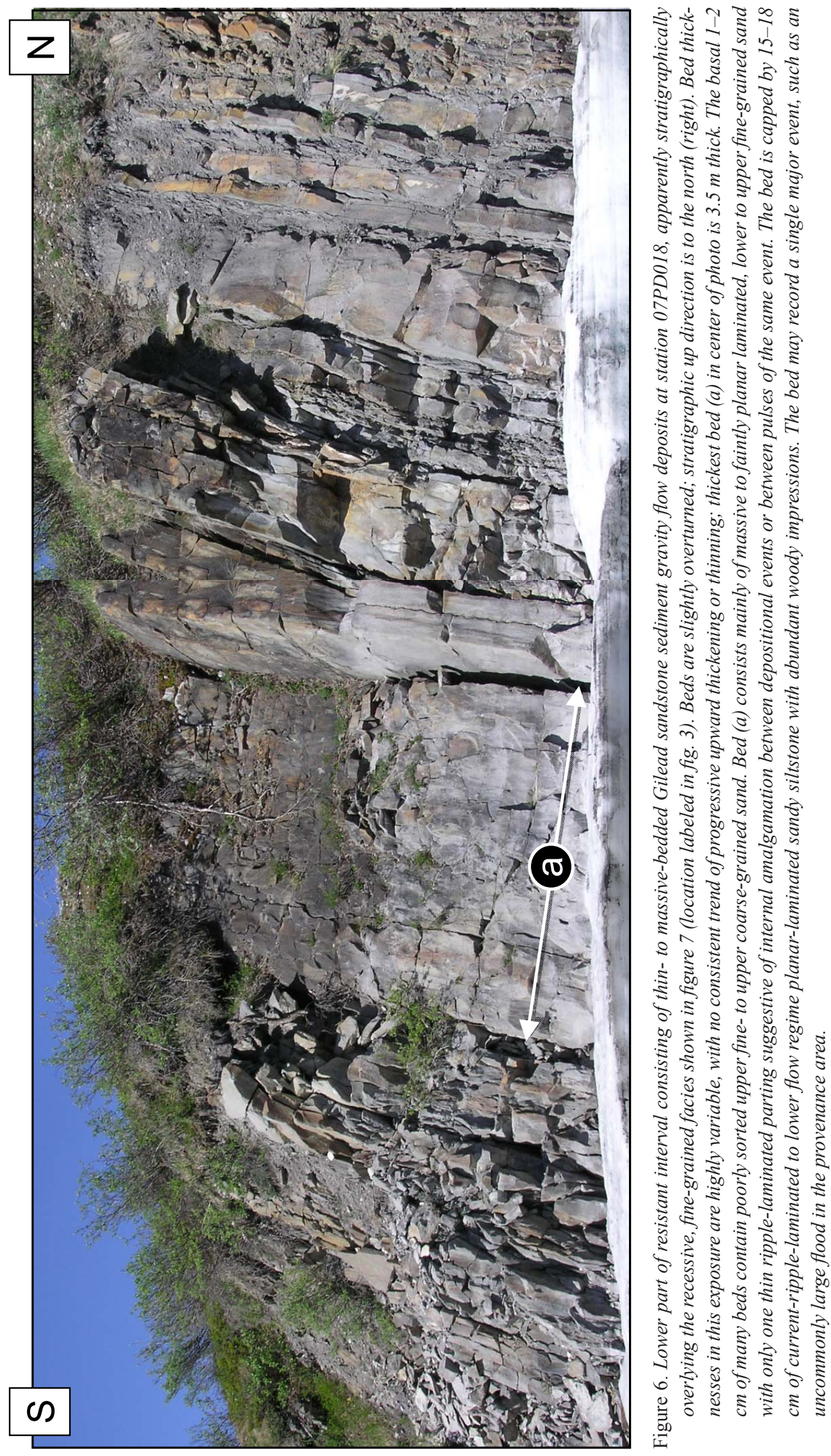

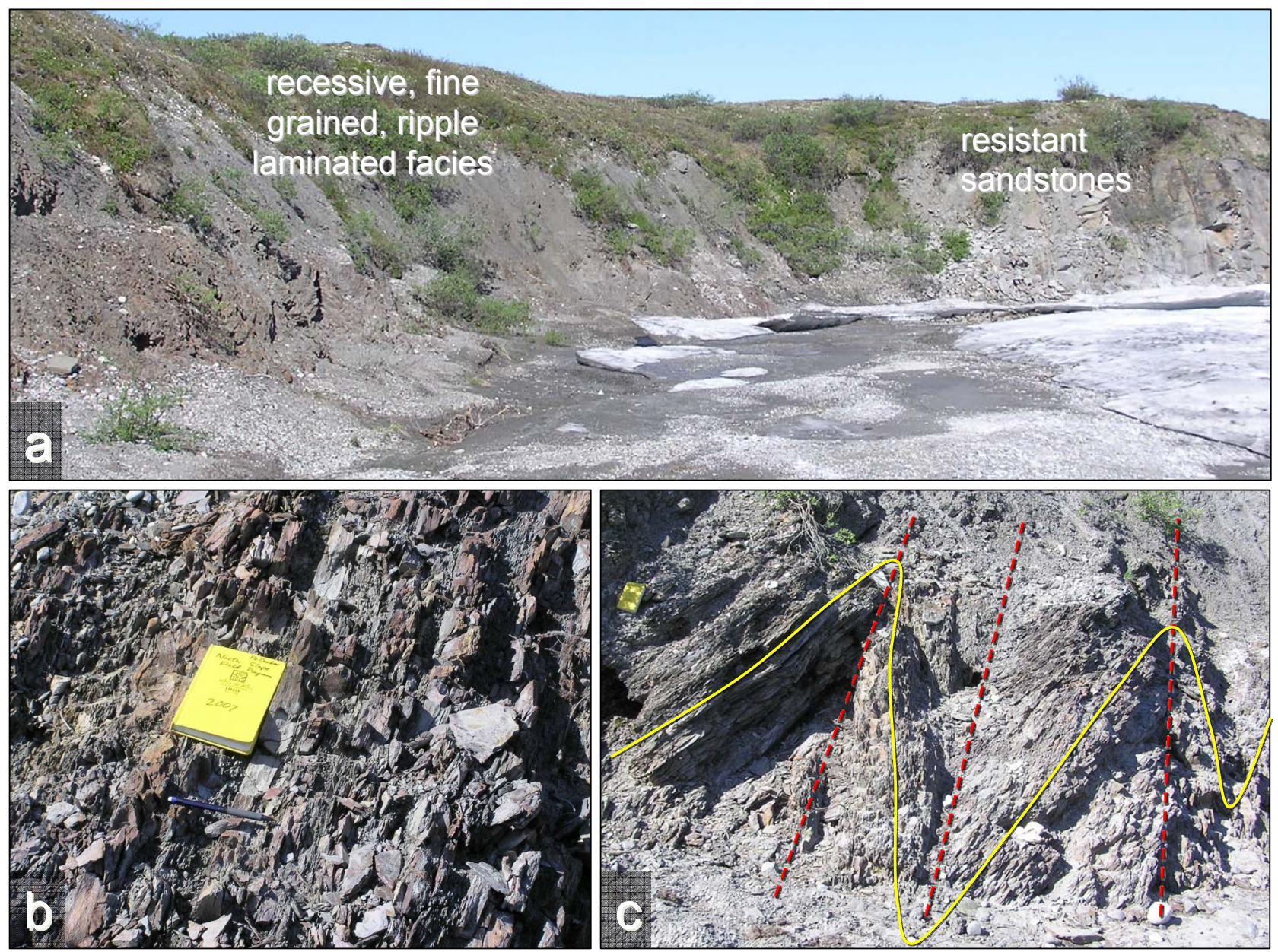

Figure 7. Steeply dipping, locally tightly folded, fine-grained sandstone and siltstone ripple-laminated facies of the Gilead sandstone on the Ivishak River at station 07PD018 (location labeled in fig. 3). (a) Outcrop overview looking northwest shows recessive bank outcrops visible in close-up photos. Overall stratigraphic up direction is to the right (north). The overlying light gray resistant sandstone interval at right is shown in fig. 6. (b) View to west of characteristic rusty reddish-brown to iridescent ripple-laminated beds; flat bed bottoms and rippled tops indicate beds are overturned, with stratigraphic up to the north (to right). (c) View to west of tight, north-verging chevron folds in sandy siltstones. Field notebook in shade at left for scale. These incompetent, fine-grained intervals localize deformation, recording much higher internal strain than the adjacent competent, sand-rich intervals that have experienced the same amount of tectonic shortening. Figure 12 shows area immediately south (left) of these exposures.

bentonitic, organic fissile shales are also present in the central and northern parts of the Ivishak River transect; in the absence of age control to the contrary, we assume those shales are somewhat younger Late Cretaceous in age, and do not consider them part of the Gilead succession. We await biostratigraphic and radiometric results from 2007 samples to further evaluate the ages of these intervals.

\section{Stratigraphy of the Gilead Syncline and Gilead Creek Traverses}

A traverse $5 \mathrm{~km}$ long beginning at the Kingak Formation on Kashivi Creek to the uppermost horizons in the hinge of the openly folded Gilead syncline (fig. 3) permitted investigation of the most continuous and least deformed stratigraphic section of Gilead sandstone. A second traverse began in Gilead sandstone on the ridgeline occupied by benchmark Shek and continued $8 \mathrm{~km}$ northward, following Gilead Creek through highly folded and thrust-faulted Gilead and Upper Cretaceous sandstones and mudstones, ending in Canning Formation (fig. 3). Several tight folds and probable faults exist between these two traverses, and it is unclear how to correlate between them due to the absence of good marker beds. Additional foot traverses near the east end of Gilead syncline focused primarily on structural relationships near the basal Brookian contact. 
The Gilead syncline traverse begins on Kashivi Creek (fig. 3; Keller and others, 1961) at an outcrop near the top of the Kingak Formation, where splintery, dark gray, micaceous, silty shales with sideritic concretionary horizons are highly deformed by north-vergent, moderately west plunging angular folds. Prior sampling in this outcrop has yielded Valanginian foraminifera and Kimmeridgian to Valanginian palynomorphs, making this shale largely timeequivalent to the Miluveach Formation of subsurface usage (Carman and Hardwick, 1983). An estimated $50 \mathrm{~m}$ of cover separates this Kingak outcrop from an exposure containing a few meters of nearly undeformed, micaceous, rusty-weathering and iridescent mudstone with thin interbeds of planar- and ripple-laminated siltstone and lower very fine sandstone; the age of these fine-grained clastic beds is uncertain. They appear similar to the fine-grained recessive intervals present elsewhere within the Gilead sandstone, and are tentatively assumed to be Brookian deposits that forecast the deposition of the overlying thicker and coarser-grained beds. Further constraints on the age of this interval may emerge from biostratigraphic analyses of 2007 samples.

The base of the more continuous Gilead sandstone exposures is in largely amalgamated, thin- to massive-bedded upper very fine to lower fine-grained quartzose, lithic, micaceous sandstones that closely resemble those on the Ivishak River except in their weathering character. These outcrops are typically extensively lichen-covered and badly frost-shattered, but they contain many of the load casts, convolutions, grooves, flutes, and partial Bouma intervals (Ta, Tab, Tabc, etc.) described from the Ivishak River transect.

Rare ammonites have been found as float from the lower part of the succession at Gilead syncline. One collected during a previous field season is tentatively assigned to the genus Gastroplites (fig. 8), of probable Albian age (R. Blodgett, oral commun., 2006). This cast, along with a similar but smaller and more fragmentary ammonite impression found in 2007, will be submitted by DGGS for more specific identification. If trace fossils exist at all in the Gilead syncline section, they are even rarer than in Ivishak River outcrops. We noted no traces in our two-day traverse.

Although the Gilead unit has been described previously as mainly non-channelized (Reifenstuhl, 1989; 1991; Pessel and others, 1990), we identified a sizeable submarine channel in the lower part of the succession on Kashivi Creek (fig. 9). The channel margin truncates at least $2 \mathrm{~m}$ of dark gray mudstones on a stair-stepped surface. The lowest exposed channel-filling unit (possible thalweg deposit) consists of blocky sandstone beds with thin, finergrained interbeds. Sandstone beds encased in mudstone farther up the channel margin appear rotated by slumping into the channel. Higher in the channel-fill succession, apparent angular discordance between beds suggests a second, slightly younger thalweg, though this merits confirmation by closer examination.

Sedimentary features interpreted to represent shelfal or shallower settings have been described previously from the middle to upper part of the section at Gilead syncline (LePain and Kirkham, 2002), including hummocky and trough cross-stratification and climbing ripples (Reifenstuhl, 1989; 1991). In our traverse of the syncline, possible

Figure 8. Ammonite cast collected during previous field season as float from the lower part of the Gilead succession at Gilead syncline. Tentatively identified to the genus level as Gastroplites, it is probably of Albian age. More specific identification is planned on this and a smaller ammonite fragment impression found during 2007 in float of submarine channel fill at location of figure 9 .

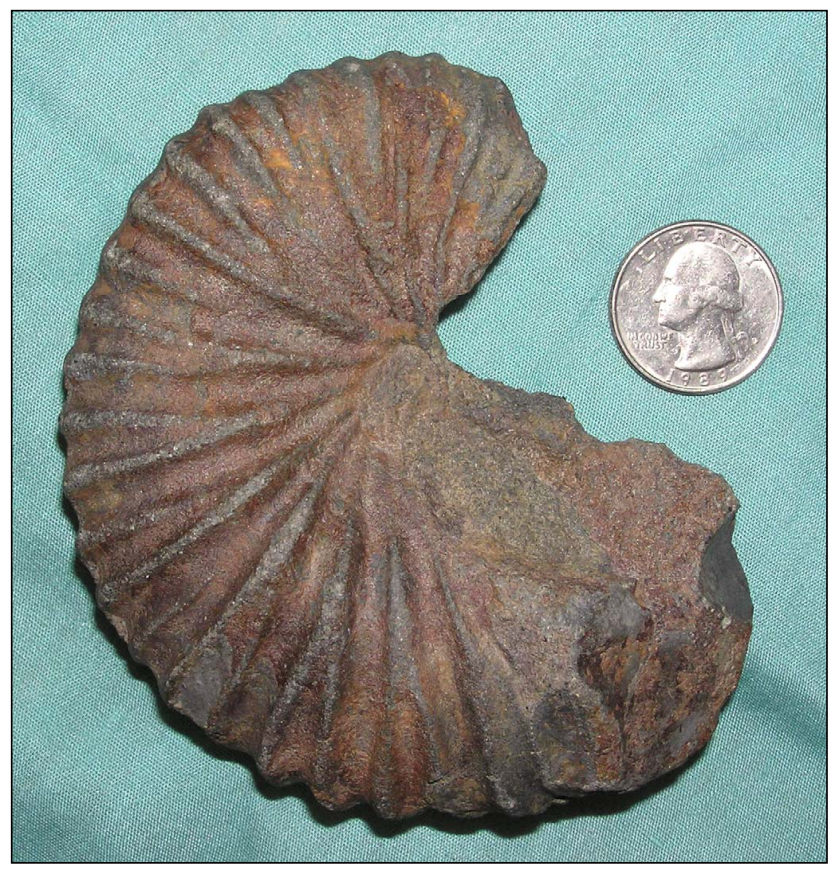



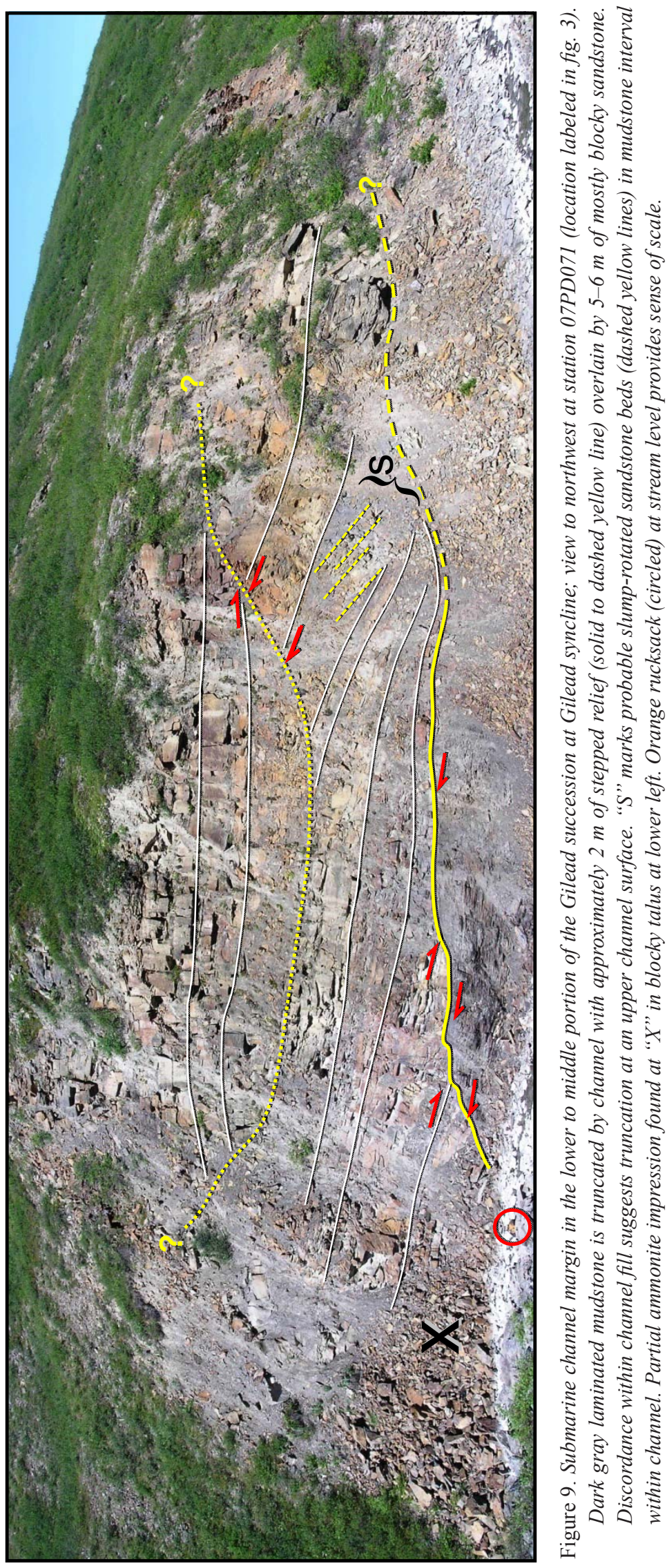
hummocky beds were few, scattered, and nowhere positively identified. One of the thickest ledge-forming packages of the amalgamated sandstone facies contains a sandstone bed $5 \mathrm{~m}$ thick made up entirely of east-prograding climbing ripples. Higher in the section, we located several examples of probable trough cross-bedding, and a few of apparent swaley cross-stratification (fig. 10). However, by themselves, trough cross-bedding and climbing ripple lamination are not diagnostic of shallow water conditions, as they occur in a range of environments including fluvial, shelfal, and deepwater settings, and are mostly indicators of current strength, grain size, and sediment supply. Furthermore, in the Gilead sandstone, these possible wave-influenced sedimentary structures are everywhere closely affiliated with features such as loads, grooves, flutes, and Bouma-like successions characteristic of sediment gravity flow deposits.

North of Gilead syncline, the Gilead Creek traverse extended the documented distribution of many of the same characteristics described along the Ivishak River and at Gilead syncline. For example, at the southeast end of the traverse on the ridge topped by benchmark Shek, the Gilead comprises numerous benches of upper fine- to lower medium-grained, medium greenish-gray-weathering amalgamated sandstone rich in metamorphic lithic clasts. White mica and conspicuous phyllite fragments appear to be important framework constituents of the coarser beds. Abundant lichen cover and frost shattering obscures many sedimentary structures, but massive, planar-parallel, and ripple-laminated (Bouma Ta-Tb-Tc) intervals are evident in the amalgamated sandstones, as well as a few probable
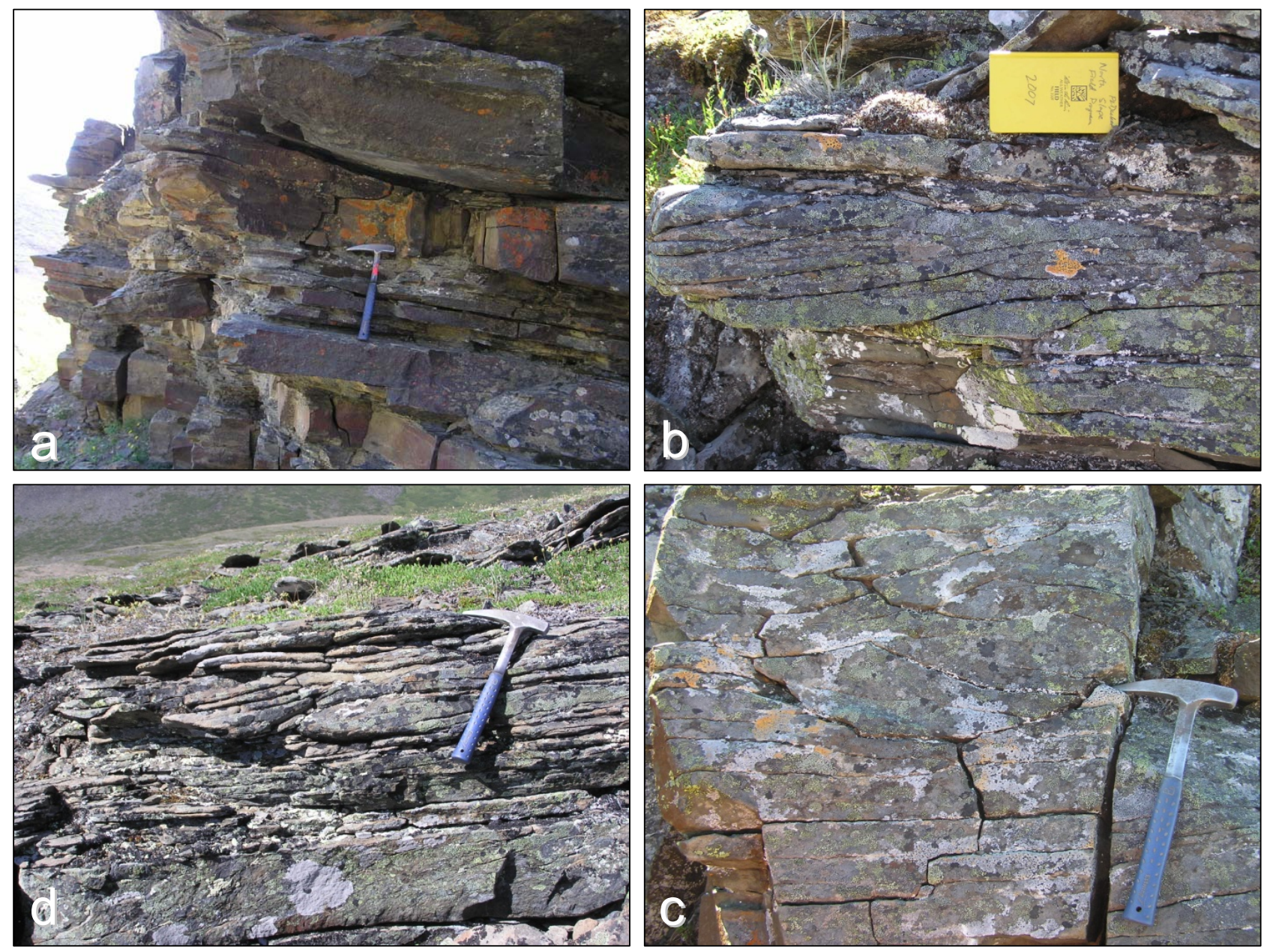

Figure 10. The middle and upper portions of the Gilead sandstone at Gilead syncline host occasional features that can be construed as evidence of wave reworking of sands that nearby features (not necessarily present in photos) indicate were most likely deposited from sediment gravity flows. (a) Medium bed with flat base at hammer head and convex-upper surface may contain large-scale hummocky bedforms with wavelengths of 2.5-3 m, but it is interbedded with sandstones marked by load casts, scour and fill features, planar-laminated beds, and current-ripple-laminated caps consistent with sediment gravity flow deposition. (b-d) Possible trough cross-beds and possible swaley cross-stratification immediately left of hammer in (d). 
trough cross-beds. North of this ridge, Gilead Creek appears to flow mostly down-section through alternating cycles of medium- to thick-bedded sandstones and thinner-bedded turbidites, including substantial covered intervals. It is our impression that the ridge-forming, amalgamated sandy packages become thinner, and that the recessive, heterolithic, thin- to medium-bedded sandstone and mudstone packages become thicker and represent more of the section northwest of benchmark Shek than to the south in Gilead syncline. This requires more quantitative evaluation since it may relate significantly to the north-south lateral continuity of the Gilead unit.

\section{Stratigraphic Interpretations and Working Depositional Model}

Molenaar and others (1984) interpreted the Gilead syncline section as consisting mainly of deep water turbidites. Huffman and others (1985, p. 68) interpreted a broader spectrum of depositional settings, and described the stratigraphic section as constituting a thick deep-marine turbidite sequence overlain by thick shallow-marine deposits with a thin fluvial section at the top; like Keller and others (1961), they interpreted it as largely Nanushuk-equivalent. Reifenstuhl (1991) inferred a middle shelf setting dominated by single-event processes such as storm-surge ebb flow and turbidity currents. Schenk and Bird (1993) concurred with Molenaar and others (1984) that the unit consists mainly of turbidites, and speculated that it probably represents lowstand fan deposition from one or more depositional sequences. We agree that the sand-rich cycles record some sort of event deposition, but are not convinced that they include shallow-marine to nonmarine deposits, though we locally observe a few instances of possible wave-related or combined-flow sedimentary structures. We refrain here from using the term "turbidites" to describe the thicker bedded, amalgamated sandstone facies intervals to avoid confusion with classical thin-bedded, unidirectionally graded turbidites. The term is more appropriately used to describe the recessive, much thinner bedded to ripple-laminated sandy siltstone to mudstone facies of the Gilead unit.

We find ubiquitous evidence for sediment gravity flow as the dominant agent of deposition throughout the Gilead sandstone, namely the partial Bouma-like successions and associated tractional and dewatering features. In the amalgamated facies association, we interpret internally structureless sandstones to represent rapidly emplaced, frictionally-frozen slurries. The overlying upper flow regime planar lamination records the reworking of such slurry beds and deposition from the traction carpet. Loaded bases and convolutions testify to rapid compactional dewatering accompanying sudden deposition. Waning flow velocity produces the upper flow regime current ripples and lower flow regime planar laminated siltstones in the late stages of flow events. The high degree of amalgamation of high energy $\mathrm{Ta}$ and $\mathrm{Tb}$ sandstone beds suggests either very frequent or sustained, possibly surging flow events rather than occasional turbidity currents produced by slope failure as the depositional process for the sand-rich facies association.

The presence of both upward-coarsening/thickening and upward-fining/thinning trends could indicate that the depositional environment was subject to progradational and retrogradational fluctuations, or it might simply reflect aggradation accompanied by lateral migration of a sand-prone channel belt. Clearly, the channelized succession incised into fine-grained facies on Kashivi Creek at Gilead syncline (fig. 9) locally provides unequivocal evidence of sandy submarine channel systems.

We consider it plausible that some of these sands represent hyperpycnites, that is, high-density sediment gravity flow deposits fed by sustained, fluctuating to quasi-steady flows with a high freshwater component that evolve from sediment-laden fluvial systems debouching into the subaqueous environment (Mulder and Syvitski, 1995). Hyperpycnal flow deposits have been recognized in association with deepwater lowstand systems, particularly where connected to shelf-edge deltas or narrow shelves (for example, Plink-Björklund and others, 2002; Petter and Steel, 2006), but they have also been described in flood-dominated deltaic environments (Mutti and others, 2003) and prodelta settings subject to storm wave reworking (Myrow and others, 2002). The near absence of trace fossils and paucity of megafossils indicates an environment hostile to marine organisms. Low salinity and high suspended sediment concentrations are two of the most common stress factors invoked to explain such conditions and both are characteristic of environments dominated by hyperpycnal flow. The presence of consistently oriented climbing ripples throughout a bed $5 \mathrm{~m}$ thick, clear evidence of a persistent current and very high sediment load, is also characteristic of hyperpycnite deposits (Mulder and others, 2003).

The lateral continuity and correlatability of the Gilead sandstone as a genetic unit remains a matter of speculation. It appears to be largely age-equivalent to parts of the Albian-Cenomanian-aged Torok and Nanushuk Formations. The Gilead name has been applied only in the Gilead Creek-Ivishak River area, but the succession closely resembles much of the Arctic Creek unit and Bathtub Graywacke in the Arctic National Wildlife Refuge (Molenaar and others, 1987; Detterman and others, 1975; Decker and others, 1988; Robinson and others, 1989; Mull and Decker, 1993) and the informally named Juniper Creek sandstone in the Kavik River area (Wartes and others, 2007). As shown in figure 1, the Bathtub Graywacke lies at nearly the same latitude as Gilead syncline. 
The Arctic Creek unit and Juniper Creek sandstone are considered to have been thrust northward to their present positions along a more northerly trend; structural restorations are loosely constrained, but it is possible that these units would restore to approximately this same latitude.

Lithologically, Gilead sandstones are also similar to isolated ridgeline outcrops visited near the Lupine River in 2007 some $20 \mathrm{~km}$ west of the Ivishak River. Figure 11 shows a comparison of our $160 \mathrm{~m}$ measured section with the well logs from the base of the sand-prone lower Brookian interval in the Lupine Unit 1 well. It is immediately clear that the thicknesses of the alternating sand-dominated and finer-grained cycles are of the same order in both sections. Furthermore, we interpret a close correspondence in the positions of upward-coarsening and upwardfining successions and note the possible correlation of certain surfaces within these larger cycles. These striking similarities in stratigraphic architecture argue that the Gilead sandstone is, at a minimum, a good analogue for the lower Brookian sand-prone interval in this well and adjacent areas of the foothills, and may actually be directly correlatable across the $24 \mathrm{~km}$ east-west distance between the well and the outcrop section.

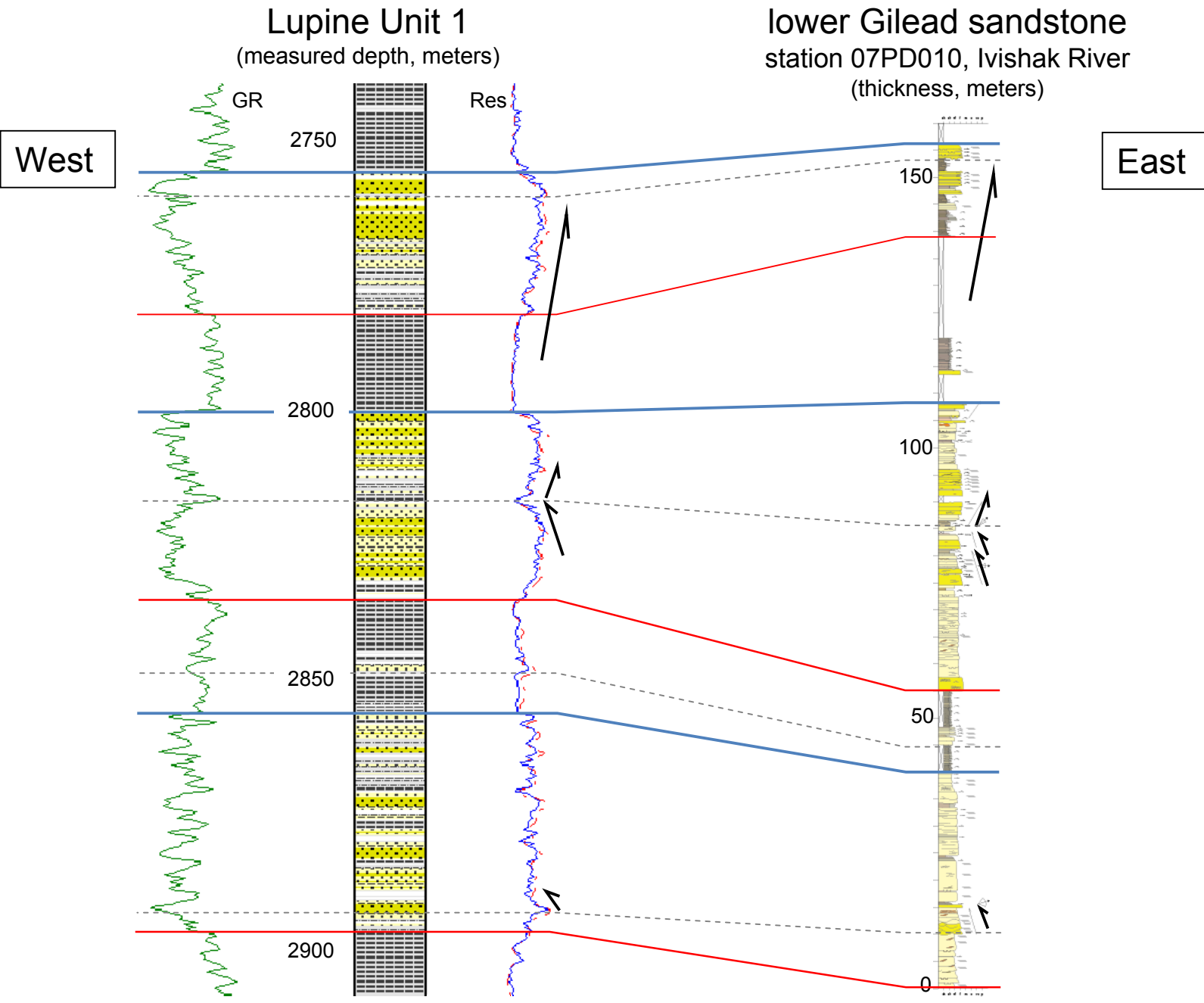

Figure 11. Comparison of the stacking architecture of the lowermost exposures (probable basal portion) of the Gilead sandstone on the Ivishak River with the basal part of the sand-prone lower Brookian interval (approximately 9,000-9,500' MD) in the Lupine Unit 1 well $24 \mathrm{~km}$ to the west. Alternating large-scale, sand-rich, and finer-grained cycles are of similar thicknesses, and internal cycles and surfaces interpreted from grain size and bed thickness variations suggest these may be time-equivalent units despite the distance between locations. If so, these variations would likely reflect major changes in the sediment source area that influenced sediment supply or hydraulic regime across a significant part of the basin. Paleocurrent observations from the Ivishak River measured section indicate relatively consistent flow to the east or northeast, in keeping with axial flow within the foreland basin, and further explaining the potential for correlations between these two occurrences. See figures 2 and 3 for locations. 
As mentioned above (and discussed in more detail later in this report), the Gilead sandstone was tectonically shortened and imbricated, and at least locally detached from the underlying Kingak Shale, but these facts do not require that it belongs to a far-traveled thrust or gravitational glide sheet. If it resides relatively close to its depositional location, it would appear to have a restricted north-south lateral extent, as the unit disappears entirely between benchmark Shek north of Gilead Creek and the long exposures of Neocomian through Upper Cretaceous strata along the Echooka River $19 \mathrm{~km}$ to the northeast (figs. 2 and 3).

The observations described above are mostly consistent with a model for the Gilead sandstone involving deposition by west-east-flowing currents, possibly largely in a submarine channel belt with restricted north-south dimension in the foreland basin's axial trough, and perhaps partly in shallower shelfal, slope, or ramp environments south of the foredeep. The southern basin margin may well have been a complex, tectonically active slope or orogenic wedge-top setting during deposition of the Gilead unit, locally subject to periodic or progressive shoaling above growing contractional structures. This offers one explanation of the possible reworking of sediment gravity flow deposits by wave energy in the upper part of the Gilead succession, though other, equally plausible explanations may emerge with further study. We tentatively view the Oligocene-Miocene Puchkirchen Formation of the Austrian molasse foreland basin (De Ruig and Hubbard, 2006) as a potential analogue for the Gilead depositional system. Prior to the interpretation of recent 3D seismic data, the Puchkirchen had been modeled as a simple series of lobate submarine fans. New mapping using high-resolution data shows that its dominant element is a low-sinuosity, axially confined channel belt $3-5 \mathrm{~km}$ wide and more than $100 \mathrm{~km}$ long. Such a long, narrow west-east-flowing axial channel belt system, along with slope fans on the southern basin margin, may have united the lower Brookian sand-rich successions in the Lupine Unit 1, Gilead syncline, Juniper Creek, Arctic Creek, and Bathtub Ridge areas, and would help explain their absence by pinchout just north of the basin axis (Molenaar, 1983).

\section{RELATIONSHIP OF GILEAD SANDSTONE TO UPPER CRETACEOUS UNITS}

As stated previously, a fundamental characteristic of the Brookian sequence is that it differs substantially from one part of the basin to another. This sets up a problem in areas that are both structurally complex and isolated from time-equivalent strata (such as the Ivishak River-Gilead Creek outcrop belt) that makes it difficult to unravel either the original depositional succession or develop a robust structural understanding.

In this part of the foothills, Albian through lower Campanian rocks are dominated by deepwater turbidites and other sediment gravity flow deposits, and formation identifications on the basis of field criteria can be highly speculative in isolated outcrops. It is harder still to piece together (with confidence) the complete original stratigraphic succession where such inherently similar units are dismembered and rearranged by structures that are themselves only partially exposed. For these reasons, it remains unclear how the top of the Gilead unit should be defined, either lithologically or in terms of precise geologic age.

Biostratigraphic constraints on the upper Gilead contact are sparse, and in some cases, may be conflicting. The youngest preserved strata from the core of Gilead syncline are of Cenomanian or younger age, based on a single specimen of the bivalve Inoceramus dunveganensis (Reifenstuhl, 1991), but these beds do not necessarily represent the depositional top of the succession. The Turonian bivalve Inoceramus (Mytiloides) labiatus (Molenaar and others, 1984) has been identified in sandstone outcrops of the northern Ivishak River traverse and along strike to the northeast on Gilead Creek (fig. 3; Reifenstuhl, 1991), but it is not clear whether these Turonian strata are mappably distinct from the Gilead sandstone as described to date. Further complicating this question is the fact that the collection location on the Ivishak River is also the recorded site of a bivalve identified as Inoceramus anglicus (Woods) of middle to late Albian age (Miller, 1982). This may be a different interpretation of the same fossil as the Turonian Inoceramid later reported from the same location by Molenaar and others (1984).

In the Brookian sequence, abundant pyroclastic content, both as discrete bentonite horizons and as dispersed tuffaceous debris, has long been recognized as characteristic of Cenomanian and younger Cretaceous strata (for example, Whittington, 1956). Thus, lacking biostratigraphic control to the contrary, Gilead beds containing bentonite laminae are inferred to be from the upper part of the succession. More work is needed to determine if an objective bentonite content threshold separates upper Gilead intervals from the Seabee or Canning Formations. Bentonite-rich, fissile, organic shale intervals are present among the sandier sections at several locations along both the Ivishak River and Gilead Creek traverses. They likely reflect relatively widespread (correlatable) transgressive to maximum flooding episodes, and it is hoped they will yield biostratigraphic control that may further define the ages of the adjacent sandstones and help reconstruct the larger mid- to Upper Cretaceous stratigraphic sequence. We also collected samples from a number of tuffs and bentonites in the hope that they will yield crystals dateable by $\mathrm{Ar} / \mathrm{Ar}$ or $\mathrm{U} / \mathrm{Pb}$ geochronology. 
At the south end of a series of outcrops beginning at station 07PD018 on the Ivishak River (fig. 12), an upright, gently dipping section of bentonitic mudstone on the south side of a small gully probably represents either Upper Cretaceous Seabee or Canning Formation. These beds are medium gray, popcorn-weathering, and contain large siderite concretions and concretionary bedding. On the other side of the gully just a few meters to the north lies an overturned section of contorted, rusty brown weathering, fine-grained Gilead facies that contains only sporadic, very thin bentonite laminae (figs. 7 and 12). The contact between these two lithologically contrasting units at or near the gully is not well exposed. During fieldwork, we inferred a fault contact at the gully. We look forward to re-examining this outcrop to evaluate whether it could instead contain a (local?) angular unconformity between these different rock units. Either way, this exposure is an example of the close juxtapositions of tuffaceous and less bentonitic strata that may have inspired Keller and others (1961) to hypothesize the existence of a mid-Cretaceous unconformity in this area.

Given current information, it appears possible that the Gilead succession may encompass both Albian-Cenomanian (Torok-equivalent) and Cenomanian-Turonian (Seabee-equivalent) deepwater deposits without a sharp lithologic break in the sandstones or the well-developed condensed shale that separates strata of these ages to the northwest, such as in wells in the Tarn-Meltwater area and in outcrops near Umiat. Albian to Turonian deepwater sediments in those areas were delivered from the west, having been transported first across the broad shelfal platform constructed by the eastward prograding Torok-Nanushuk depositional system. At the toe of that broad shelf platform, sediment supply was highly sensitive to being shut off by relative sea level rise; this is recorded by the condensed section at the base of the Seabee Formation in that area (the Shale Wall facies in the sense of Houseknecht and Schenk [2005] and adopted by Decker [2007]). In contrast, the Gilead study area lies far to the east of the north-south-trending segment of the final Nanushuk shelf margin. Little is directly known about the width of the shelf attached to the orogen to the south, but we speculate that the Gilead area may have been either at or just south of the basin axis during mid-Cretaceous time, with a relatively direct connection to the actively eroding orogenic belt. This may have ensured that the Gilead area had a more consistent supply of sandy sediment than the Tarn-Meltwater area during the major Cenomanian flooding event, and may have sustained nearly continuous deepwater sand deposition without the well-developed basal Seabee Formation condensed section that exists north of the foredeep axis. This scenario would be consistent with the top of the Gilead unit being a gradational contact.

Until the upper contact is better defined, it will be challenging to use the Gilead sandstone as a map unit in areas where it is associated with Turonian Seabee-equivalent and younger rocks. We hope that samples collected in 2007 will yield critical biostratigraphic or radiometric control that can be integrated with detailed petrography to develop robust criteria for distinguishing these units in the field.

\section{STRUCTURAL STYLE AND DEFORMATION HISTORY}

The topographic and structural grain of this area trends northeast-southwest. Not surprisingly, important changes in structural style and stratigraphy are observed in progressing across the grain toward the foreland from south to north along our traverses. A full interpretation of the structural observations and measurements collected along the 2007 traverses of the Ivishak River, Gilead syncline, and Gilead Creek is beyond the scope of this report. Nevertheless, the following section summarizes key structural characteristics observed on these traverses, and considers their implications for unraveling the stratigraphic record and documenting the regional deformation history.

\section{Structure of the Ivishak River Transect}

Bedding attitudes vary widely along the Ivishak River, but much of the section in the three segments of our 8.8 $\mathrm{km}$ traverse is subvertical to overturned. Though the succession becomes younger to the north in the broadest sense, common dip reversals and probable thrust imbrication make it crucial to determine the stratigraphic up direction at each outcrop. The southern portions of the Ivishak River transect include long exposures of strongly overturned beds with stratigraphic top to the north, locally rotated by more than $160^{\circ}$, resulting in overturned southward dips of less than $30^{\circ}$. These long stretches of overturned beds alternate with short exposures of upright, gently-dipping beds on the south limbs of anticlines whose axial surfaces dip to the south (fig. 13). Most fold axes plunge gently to the west, consistent with greater uplift in the nearby Echooka anticlinorium (Meigs and Imm, 1995) and other portions of the Brooks Range salient to the east.

The southern Ivishak River segment (fig. 3) contains mostly tight, asymmetric to overturned folds with south-dipping axial surfaces. They are readily observed at the outcrop scale and are reconstructed from bedding orientations at larger scales. Thrust faults are localized in the overturned limb of some, if not most, of the over- 

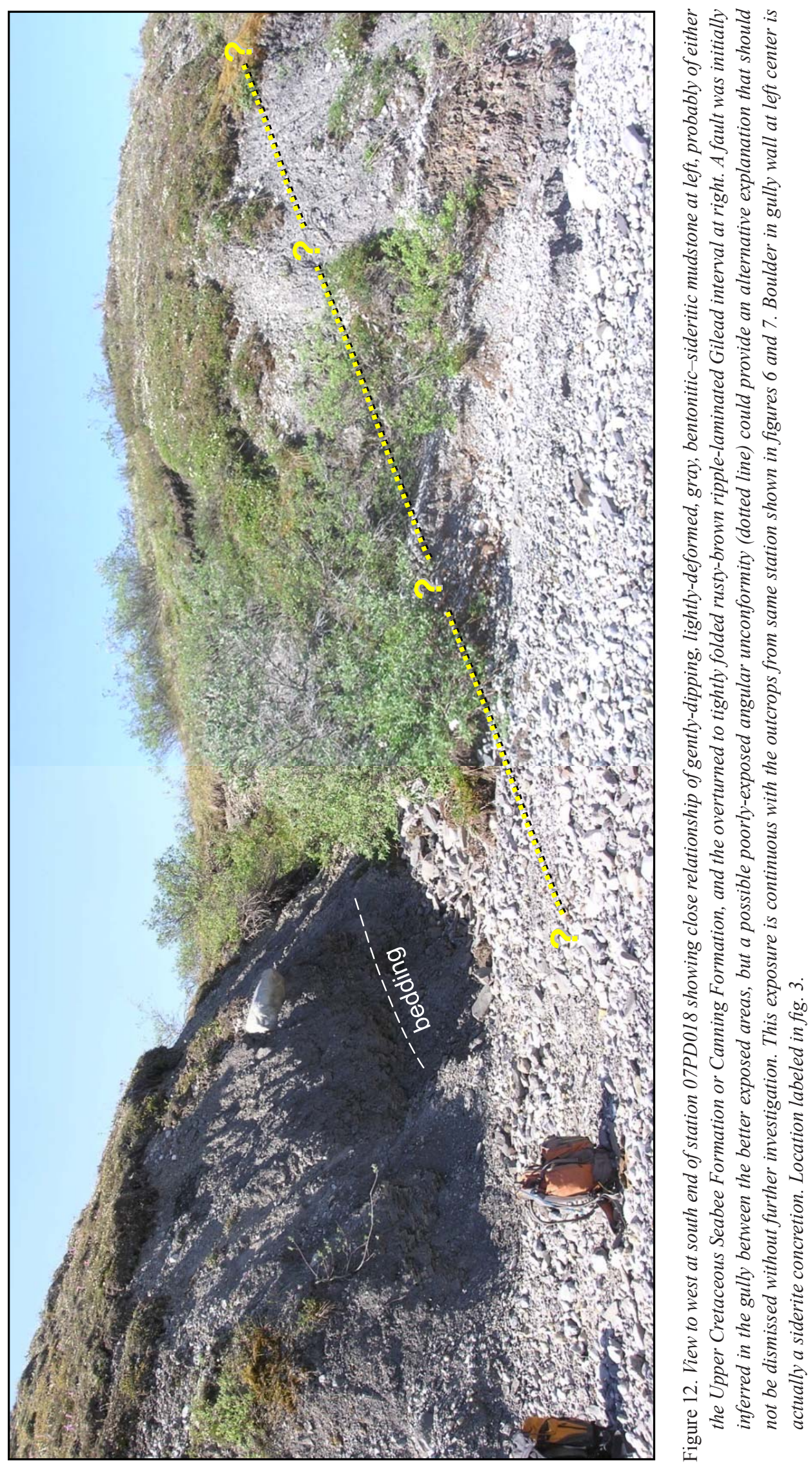
turned folds. Observed structural styles are clearly related to the mechanical strength of various units. Competent, massive-bedded sandstones form folds that are rounded and concentric at the outcrop scale, whereas incompetent very thin-bedded sandstones and mudstones commonly form chevron folds. Some folds record higher strains, becoming recumbent and even entirely inverted (downward facing).

Figure 14 illustrates a spectacular example of an outcrop-scale synformal anticline juxtaposed by faulting with a much more readily explained pair of overturned chevron folds. We interpret this set of structures in terms of a deformational sequence that may involve two distinct contractional events, or may simply reflect a change in deformational behavior with progressive shortening (fig. 15). An early phase (arbitrarily called D1 for discussion purposes) is hypothesized to have involved low-angle thrust faulting of a nearly isoclinal, recumbent, outcropscale anticline in the hangingwall above a ramp, marked by cutoff of beds in the footwall. During a subsequent deformational phase (D2, perhaps a continuation of the same event), the area of this outcrop-scale structure is hypothesized to have become the overturned limb of a lower order (much larger) north-vergent fold, rotating the earlier formed recumbent anticline through an additional $90^{\circ}$ or more, making it a downward-facing (completely inverted) fold. Shortening accompanying formation of the larger fold generated parasitic chevron-style folds in which bedding in the short limb is returned to an upright orientation, but bedding elsewhere remains overturned. The asymmetry of these chevron folds is consistent with the flexural-slip shear couple expected in the overturned limb of the larger fold.

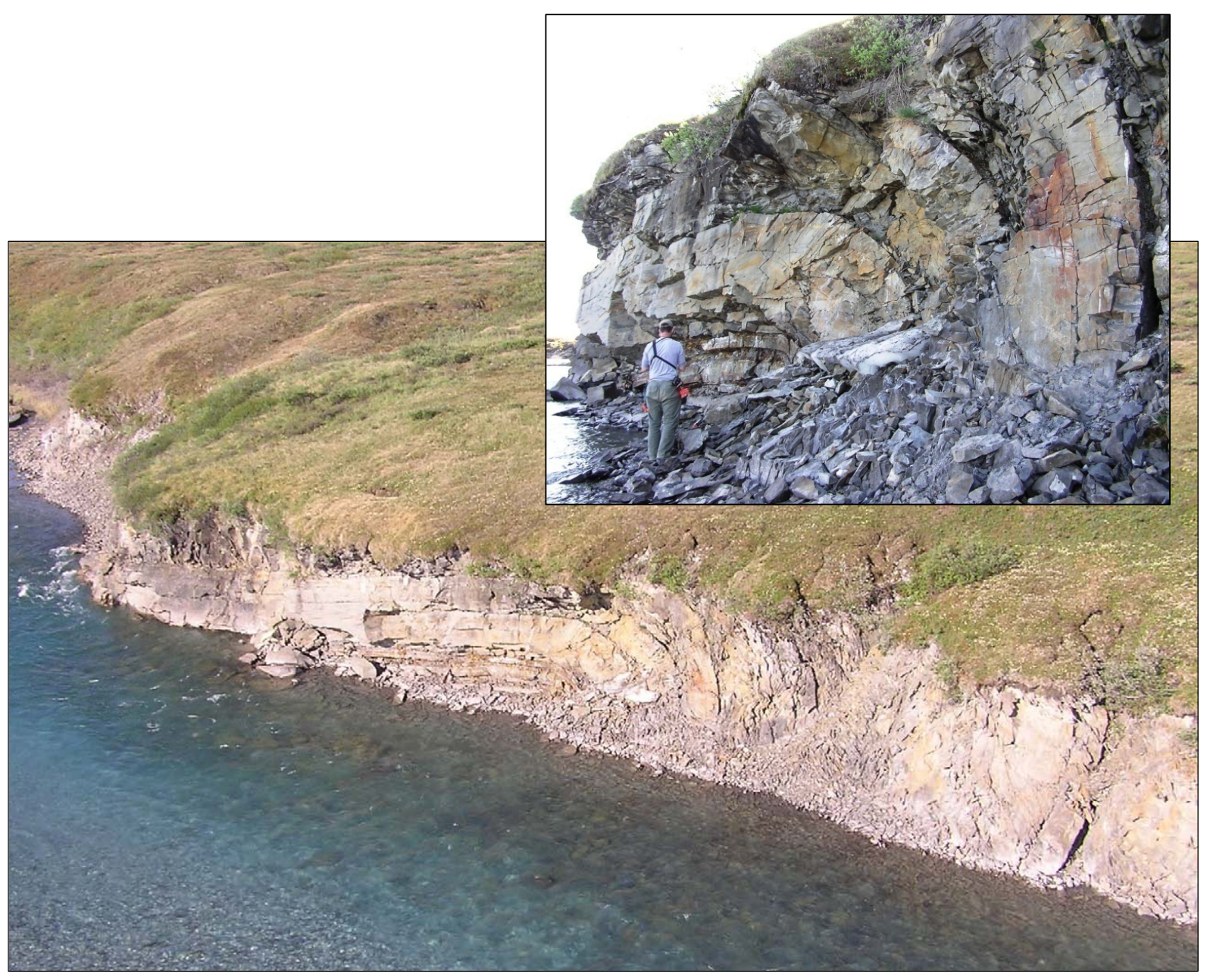

Figure 13. Overturned anticline with south-dipping axial surface in Gilead sandstone at stations 07PD014 and-015 on Ivishak River approximately $0.5 \mathrm{~km}$ northwest of the synformal anticline shown in fig. 14. This view to the west-southwest is nearly parallel to the anticlinal axis, which plunges approximately 15 degrees to azimuth 245 . The upright limb at left exposes much less section than the steep, overturned limb at right, which becomes progressively more overturned and thrust-faulted slightly farther north. Location labeled in figure 3. 

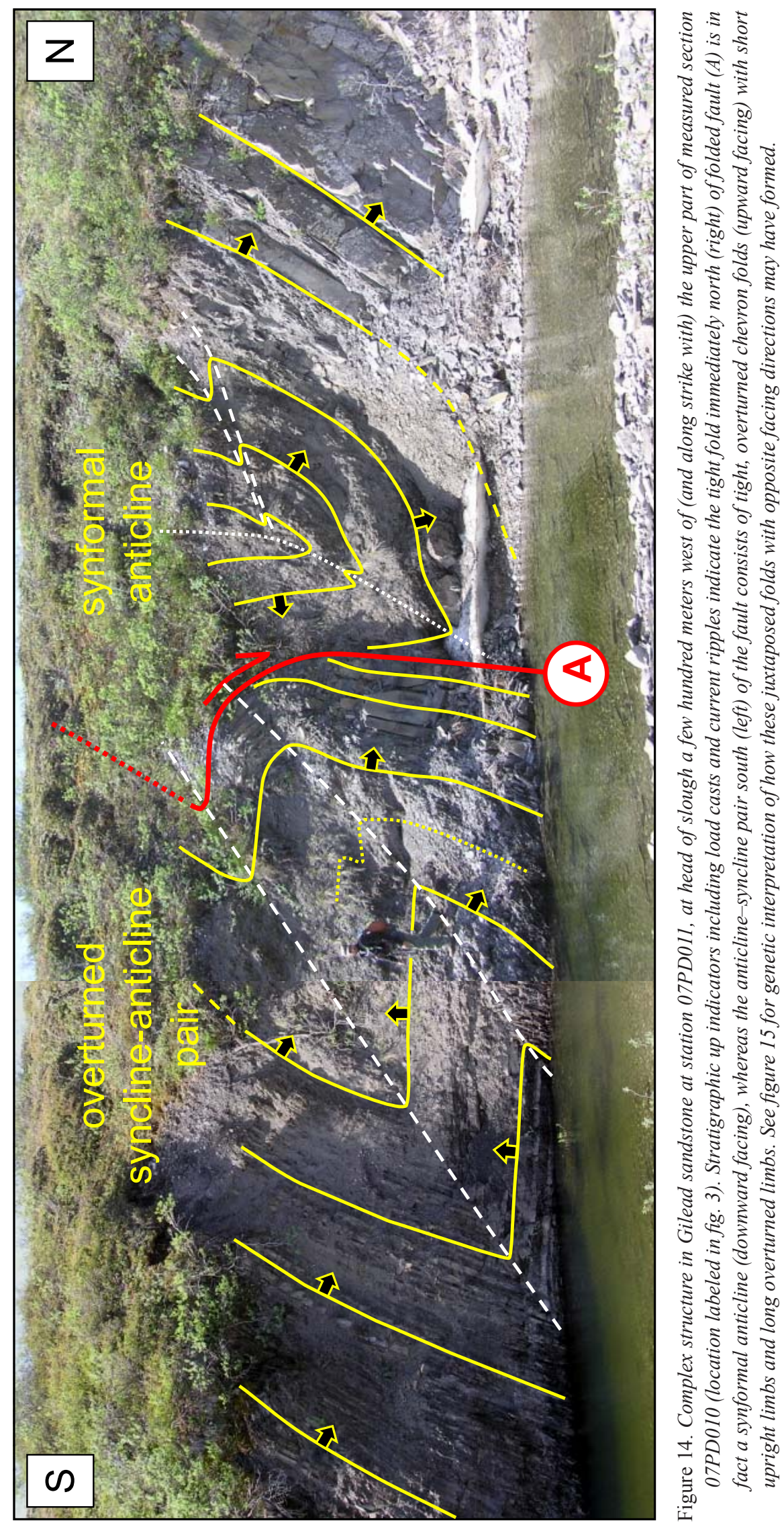


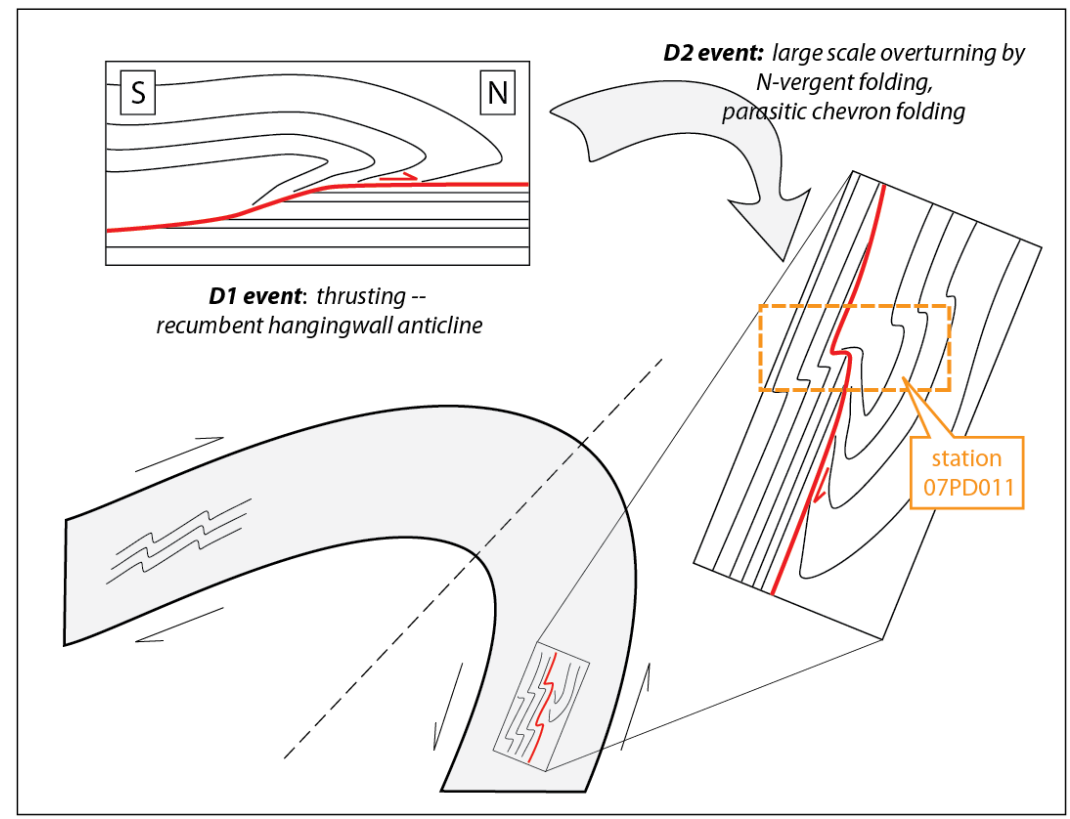

Figure 15. Structural hypothesis for development of synformal anticline, thrust, and overturned chevron folds in the Gilead sandstone on the Ivishak River at station 07PD011 (fig. 14). North-directed thrusting with development of a recumbent hangingwall anticline and footwall cutoff occurred during an early deformational phase (D1). During a second phase of deformation (D2), this location may have become the overturned limb of a large-scale north-vergent fold, in which parasitic drag fold geometries are characterized by long overturned limbs and short upright limbs. Apatite fission track analyses by O'Sullivan (1991) recognized as many as three Tertiary uplift events in this area with approximate ages of $60 \mathrm{Ma}$ (Paleocene), $45 \mathrm{Ma}$ (Eocene), and $35 \mathrm{Ma}$ (Oligocene). Further thermochronologic analyses on 2007 samples may help tie the phases of deformation described here to datable events.

On the basis of apatite fission track analyses in the Gilead area, O'Sullivan (1991) recognized three cooling events with approximate ages of $60 \mathrm{Ma}$ (Paleocene), $45 \mathrm{Ma}$ (Eocene), and $35 \mathrm{Ma}$ (Oligocene). These cooling events have subsequently been recognized across much of the northeastern Brooks Range (O'Sullivan and others, 1993; O'Sullivan, 1996), and are interpreted to reflect uplift and erosional unroofing accompanying major phases of Tertiary contractional reactivation. We collected samples in 2007 for further thermochronologic study that may help link the structural phases interpreted in outcrop to datable cooling events.

A nearly vertical fault that strikes northwest-southeast with slickenlines plunging $5^{\circ}$ southeast cuts measured section 07PD010 on the Ivishak River, offsetting the subvertical beds in a left-lateral sense by $5.3 \mathrm{~m}$. This is a fairly minor fault, but when combined with observations of dip reversal, misaligned or terminating fold hinges, and other structural discordances between outcrops on opposite sides of the river, it seems probable that this northwest-trending stretch of the river is controlled by a larger tear fault of similar orientation, allowing compartmentalization of shortening, with differences in structure east and west of the Ivishak River.

Slightly farther north in the central segment of the Ivishak River transect (fig. 3), beds are mostly upright and south dipping, becoming older to the north, the reverse of the overall northward-younging trend. Mostly northvergent structures are developed at a variety of scales, including thrust faults and open to tight folds with long upright limbs and short overturned forelimbs. In the overturned forelimb of a significant anticline near the south end, beds are locally strongly overturned with south-southeast dip as low as $29^{\circ}$. Near the middle of this segment is a symmetric to slightly south-vergent anticline-syncline pair with low to moderate dip angles and gentle plunge to the west or southwest. A south-dipping thrust cuts the north end of the central segment, carrying Gilead- or Seabee-equivalent sandstones with strong oil odor in the overturned limb of a hangingwall anticline, emplacing it above fissile to subfissile bentonitic shale, likely of the Canning Formation. This fault probably continues to 
the west-southwest through the prominent saddle between two rounded hilltops slightly lower than $460 \mathrm{~m}(1500$ $\mathrm{ft}$ ) elevation, and is interpreted to project northeast of the Ivishak River into the uplands west of Gilead syncline (figs. 3 and 16).

The northern segment of the Ivishak River traverse (fig. 3) comprises a mainly upright, south-dipping panel of Gilead sandstone and/or Seabee-equivalent sandstone and organic, bentonitic shale with locally strong oil odor. North-vergent asymmetric to overturned and locally isoclinal outcrop-scale folds and thrust-faults are common. In one area of particularly intense folding, medium- and thick-bedded sandstones are thrust-imbricated, detached from, and disharmonically folded relative to the subjacent chevron-folded laminated mudstones. Some of these are isoclinal folds whose axial surfaces have been refolded into open folds, consistent with two stages of deformation. In a gully at the north end of the northern traverse, thin-bedded sandstone, siltstone, and shale beds of probable Canning Formation are deformed into complex folds with non-linear axes. We interpret this northernmost outcrop as being in the footwall of a thrust that cores the long Aufeis anticline (Mull and Adams, 1989, p. 121-123) penetrated by the Aufeis Unit 1 well some $60 \mathrm{~km}$ to the west (fig. 3). This places the northern Ivishak River traverse on strike structurally with the lower part of the Turonian to Campanian aged Sagashak Creek section in the south limb of the Aufeis anticline, discussed by LePain and others in a separate chapter of this report.

\section{Structure of the Gilead syncline and Gilead Creek traverses}

The upland area south of the west-flowing upper reaches of Gilead Creek (fig. 3) encompasses several folds in addition to Gilead syncline, the major structure in the area. Partial remapping of these structures in 2007 was conducted (primarily by Wallace) both in the field and from aerial photography (fig. 16). Gilead syncline preserves the southernmost exposures of the Brookian sequence in this area of the mountain front; Brookian strata have been uplifted and eroded above the Echooka anticlinorium to the southeast. Gilead syncline is an open, southwestplunging "thumbprint" syncline, measuring approximately $3-4 \mathrm{~km}$ in width and $6 \mathrm{~km}$ in length, defined by the thick succession of resistant Gilead sandstone. To the northwest, between Gilead syncline and Gilead Creek lies a train of several smaller, narrow anticlines and wider synclines. They dominantly plunge to the southwest, but locally exhibit more gentle plunge to the northeast. We correlate the resistant sandstone packages exposed in these northern folds with several of the major benches from the lower and middle parts of the unit in Gilead syncline. We recognize a probable north-directed thrust fault with apparently limited displacement between Gilead syncline and the northern train of folds. This fault was mapped locally by Pessel and others (1990), and we tentatively extend its trace to the southwest toward the Ivishak River, where it may connect with the thrust described in the previous section at the north end of the central segment of the Ivishak River traverse.

Pessel and others (1990) mapped a series of gently-dipping thrusts parallel or near-parallel to bedding and with arcuate surface traces within and at the base of the succession. They drew these as top-to-south faults on their cross section, which can be interpreted as either backthrusts or out-of-syncline thrusts. Reifenstuhl (1991) interpreted thrust duplication of the upper part of the succession at one of these faults on Kashivi Creek. Although it is possible that such faults may be present in the area, we have a different impression of the Kashivi Creek fault. We interpret it as one of several steeply dipping transverse or rotational faults with fairly linear, north- and northwest-trending traces that we recognize in the area from the offset of fold hinges and resistant sandstone units. These transverse faults compartmentalize deformation within the fold train, allowing structures on either side to contract quasi-independently of each other. Two of the best-developed examples have greater map-view offset on one limb than the other. Slickenlines have not been observed on the transverse faults at Gilead syncline, and it is unclear whether they are dominated by strike-slip, dip-slip, or sub-equal amounts of both.

Without question, there are major along-strike differences in the style and magnitude of shortening within the Gilead succession. For example, the dominantly overturned section of the southern Ivishak River traverse trends into or is juxtaposed against the upright folds of the Gilead syncline area. Exposures are poor and discontinuous in the intervening low terrain, but a system of tear faults offers an attractive explanation for these differences.

As described in the introduction, there has been long-running (though mostly unpublished) discussion of whether the Gilead unit is allochthonous or parautochthonous. This question has significant subsurface implications and major bearing on paleogeographic reconstructions. The covered contact between the Gilead sandstone and the more deformed underlying Kingak Shale has been mapped as a thrust (Pessel and others, 1990; Reifenstuhl, 1989; 1991), despite the fact that it appears to consist of Albian strata overlying Valanginian-aged rocks with the apparent omission of several Lower Cretaceous units between the Gilead sandstone and the Kingak Shale. These missing units include the gamma ray zone (GRZ) of the lower Hue Shale, the pebble shale unit, the Kemik Formation, and any surface correlatable with the Lower Cretaceous unconformity (LCU); this stratigraphic interval ranges from an estimated $90 \mathrm{~m}$ to $210 \mathrm{~m}$ thick in the nearest wells. Except at decollements or in triangle zones, where 


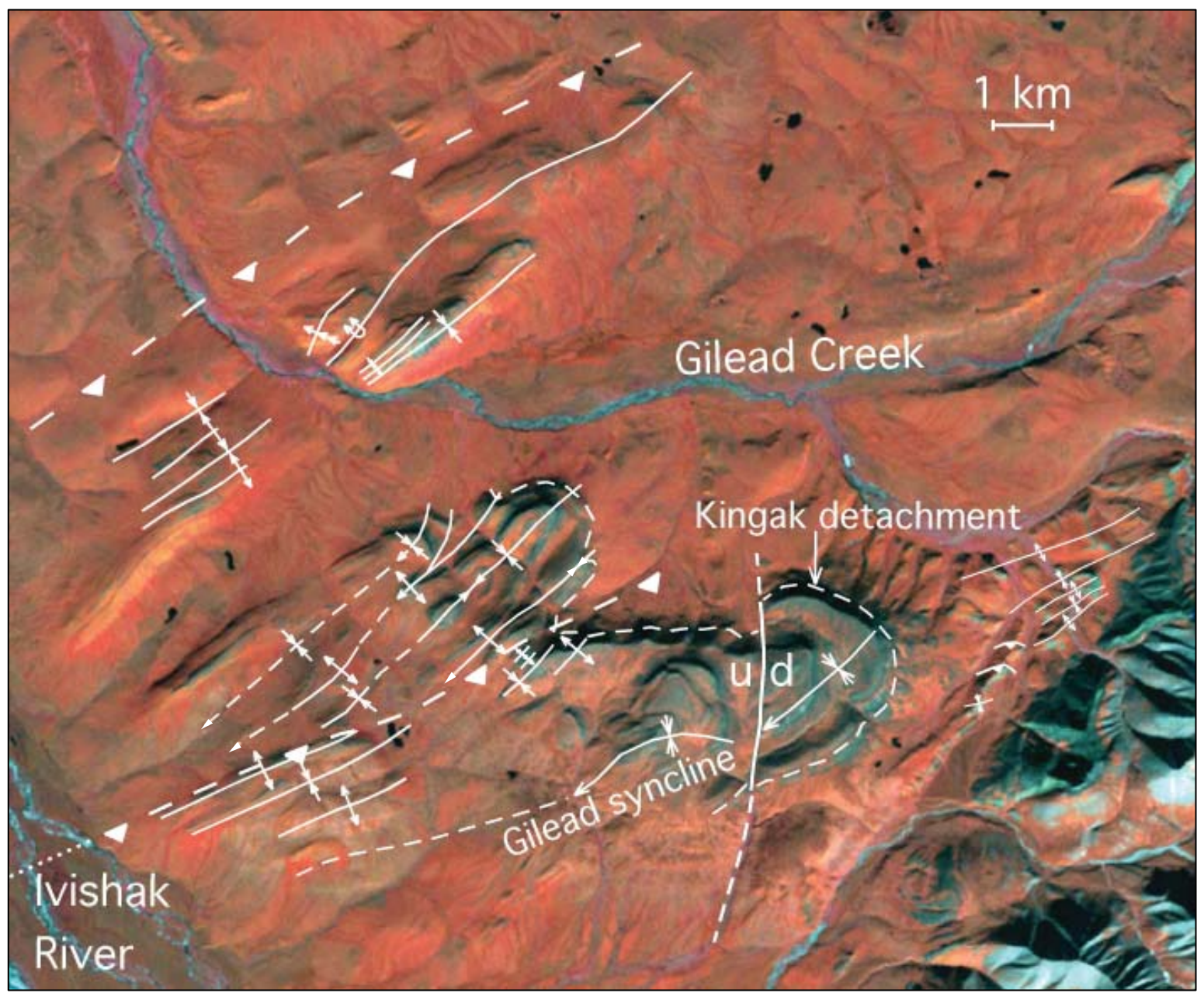

Figure 16. Simplified preliminary remapping in the Gilead syncline-Gilead Creek area from aerial photo interpretation and foot traverses conducted during 2007.

younger rocks in the passive roof of a backthrust may directly overlie older beds of the imbricated horses below, younger-over-older thrusting is unusual, and generally requires that the thrust fault cuts downsection across rocks that were previously folded or faulted to result in omission of section rather than the usual thrust repetition. This multi-stage scenario is conceivable at Gilead, but is not required to explain both the deformation in the Kingak Formation or the apparent omission of section at the contact.

The angular folds and shear fractures present in the Kingak Formation on Kashivi Creek are entirely consistent with the types of structures to be expected in this part of the mechanical stratigraphy, whether or not there is a fault of significant displacement between the Kingak and the Gilead. As an incompetent mudstone subjected to shortening along with the thick overlying succession of competent Gilead sandstone, it undergoes mostly outcrop-scale ductile flow, with folding and faulting of the brittle concretionary beds within it. Mechanical detachment of the Gilead unit from the underlying Kingak Shale (fig. 16) would be expected, whether the Gilead is a far-traveled allochthon, or simply the passive foreland-dipping roof of a north-vergent, west-plunging duplex created by the imbrication of underlying units. We confirm that the Triassic and Jurassic section structurally below and to the east of Gilead syncline is shortened by thrust-broken north-vergent folds (Meigs and Imm, 1995) with smaller wavelength and amplitude than the folds in the overlying Gilead sandstone (fig. 16).

Theoretically, the younger-over-older relationship and omission of section at Gilead syncline could also be explained with structural models involving (low-angle) normal faulting (Schenk and Bird, 1993) or top-to-north gravity gliding (C.G. Mull, oral commun., 2007). Large-magnitude Early to mid-Cretaceous extension of the overthickened orogen along shallow dipping, top-to-south normal faults has been documented in the southern Brooks Range (for example, Miller and Hudson, 1991; Blythe and others, 1996; Vogl, 2002; Vogl and others, 2002), but 
younger, top-to-north extensional collapse that could account for normal displacement of the Gilead succession on the north edge of the range has never been recognized.

Alternatively, the missing Lower Cretaceous units could be absent due to local non-deposition or may have been removed by erosion (Schenk and Bird, 1993) or mass wasting before deposition of the Gilead sandstone. The paleogeography of the Gilead area during that time is uncertain but it is sufficiently far south that it may have been too distal to experience laterally persistent deposition of the Kemik sands derived from the Barrow Arch rift margin to the north. Alternatively, the area might have been a bald subaerial high lacking accommodation space, or a bald bathymetric high, isolated from sandy sediment supply during Neocomian time. At nearly the same latitude, the Lupine Unit 1 well is the nearest and most relevant source of subsurface control. Overpressure prevented the acquisition of wireline logs across the lowermost Brookian to Kingak interval in the lower part of the well, where biostratigraphic data suggest the section is imbricated by thrust faults. However, mudlog data provide no evidence of a Kemik Sandstone interval in the well. Cuttings samples of fissile shales may be GRZ-equivalent, and numerous descriptions of floating sand grains and several instances of rounded pebbles may represent fault repetition of the pebble shale unit and/or a surface correlative to the LCU. In short, the Lupine well data support the argument that the Kemik sandstone may be absent at Gilead syncline due to non-deposition rather than because of faulting, but it offers no compelling explanation for the absence of the other Lower Cretaceous units there. Additionally, tentative correlations between the lower Gilead outcrop belt on the Ivishak River and the lower Brookian interval in the Lupine well (fig. 11) suggest that either the Gilead outcrop belt is not highly allochthonous, or that the allochthon extends at least as far west as the Lupine well.

To the north on the Gilead Creek traverse, shortening within the Gilead interval and associated Upper Cretaceous units appears to be greater than at Gilead syncline, with tighter asymmetric folds having steep to locally overturned limbs. The central part of this traverse is on strike with the northern segment of the Ivishak River transect approximately $5 \mathrm{~km}$ to the southwest, and is believed to correlate structurally to the Aufeis anticline.

Most of the section on the Gilead Creek traverse is right-side up and south dipping, yet overall, the section youngs northward from Gilead sandstone into north-dipping, progressively less-deformed Canning and Schrader Bluff Formations. This geometry is consistent with a series of south-dipping, north-vergent thrusts in the older strata, which either breach the surface or merge with a hypothetical north-dipping backthrust lying beneath the Upper Cretaceous units. The north dip of the younger strata may reflect deeply rooted folding, or might reflect a northward-tapering triangle zone within the Brookian sequence.

Beds are locally steeply overturned in the thrusted forelimb of a north-vergent anticline at station 07PD127 in the southern part of the traverse (fig. 17). This is the perhaps the best-exposed thrust fault we have encountered in the study area. The amount of offset is uncertain, but Gilead succession rocks make up both sides of the fault. It exhibits a substantial damage zone consisting of shredded sandstone and finer-grained lithologies from both the overturned hangingwall and upright footwall beds. A large, lozenge-shaped shear boudin in the gouge zone has tails and internal shear fractures consistent with top-to-north transport. Interestingly, a minor thrust-faulted kink fold in the overturned limb a few meters south of the major thrust is consistent with the opposite sense of shear. It is interpreted as a probable parasitic drag structure generated by the flexural slip shear couple expected for the overturned limb. It is analogous to the folds with short upright limbs that are present in the overturned limbs of larger folds in the "D2" phase described earlier, but it is unclear whether it is of the same age.

Both north- and south-vergent asymmetric folds are present on Gilead Creek. North of the location where Reifenstuhl (1991) reported the collection of the Turonian bivalve Inoceramus labiatus (station 07PD133, fig. 3), axial planes dip mainly to the northwest, and folds appear to be southeast-vergent (fig. 18). Whether this reversal in axial planar dip is accompanied by one or more northwest-dipping (southeast-vergent) backthrusts is not clear.

\section{SUMMARY AND CONCLUSIONS}

The Gilead sandstone in the study area is dominated by alternating facies developed in units tens of meters thick. These alternating cycles consist of (1) very sand-rich, medium to massive bedded, highly amalgamated intervals interpreted as hyperpycnites or other high-density sediment gravity flow deposits, and (2) very thin bedded, current-ripple-laminated intervals consisting of more classical turbidites. The fine-grained facies appears to constitute a significant percentage of the unit's overall stratigraphic thickness, suggesting broader terms such as "Gilead unit" or "Gilead succession" may be more appropriate when referring to the interval in its entirety. Transitions between these contrasting lithologies are variable, including gradual upward-coarsening and -thickening progradational cycles, upward-fining and -thinning retrogradational cycles, and sharp-based and sharp-topped intervals that appear to record either abrupt avulsion events or changes in sediment supply within the provenance area. 
The upper contact of the Gilead sandstone is not defined, and hence, the unit's complete stratigraphic thickness remains unknown. The nature of the stratigraphic section between the Cenomanian upper Gilead and Campanian Canning Formation is difficult to reconstruct with confidence. This part of the section is eroded at Gilead syncline, and where Turonian rocks and younger beds are present on the Ivishak River and Gilead Creek, the problem remains challenging because of structural dismemberment, common dip reversals, and to date, insufficient robust biostratigraphic and chronostratigraphic age control. The Gilead sandstone at Gilead syncline is far less deformed than on the Ivishak River; steeply dipping tear and rotational faults recognized in 2007 were mapped previously as thrust faults (Pessel and others, 1990; Reifenstuhl, 1989; 1991), but we concur with the correlation of units that was used by Reifenstuhl to offset the measured section at one of these faults $(1989 ; 1991)$. However, because no contact is preserved with a lithologically distinct overlying succession, the $850 \mathrm{~m}$ thickness measured there (Reifenstuhl, 1989) represents a minimum thickness.

Compositional and textural changes appear gradational from Albian strata of the lower Gilead into sandstones that are of probable Turonian age and thus laterally equivalent to the Seabee Formation. Depositional processes are dominated by sediment gravity flow throughout. At this point, we tentatively reconcile these observations as consistent with a depositional model that involves nearly continuous Early to Late Cretaceous sand deposition in a west-to-east flowing axial channel belt system, and perhaps in shallower environments toward the southern

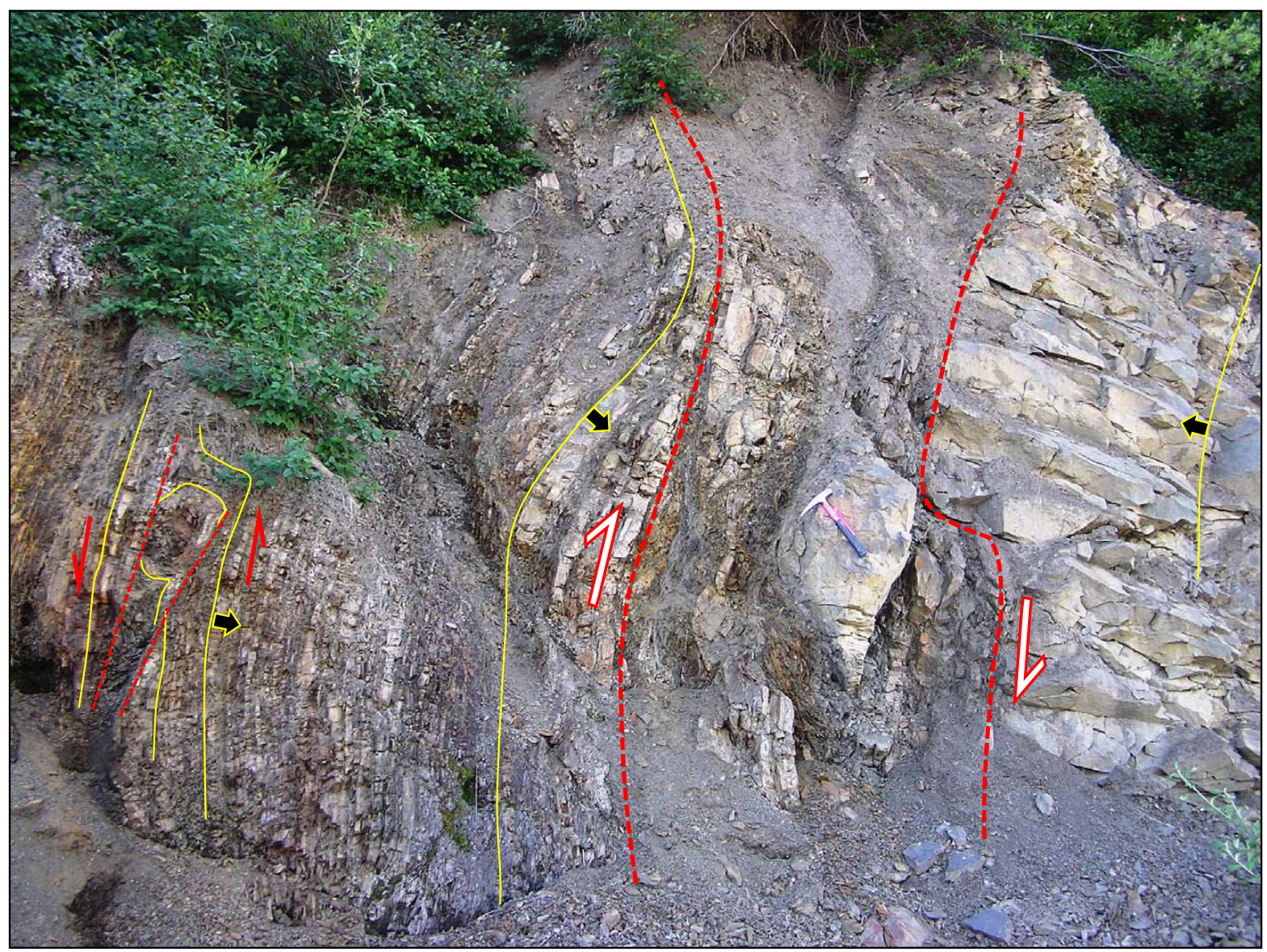

Figure 17. View to west of recessive, fine-grained, thin-bedded facies in the overturned forelimb of a north-vergent anticline thrust over upright thick- to massive-bedded Gilead sandstone on Gilead Creek at station 07PD127 (location labeled in fig. 3). Small arrows indicate stratigraphic up direction. Hammer rests on lozenge-shaped shear boudin derived from the footwall within thick damage zone approximated by dashed red lines in which shear indicators are consistent with top-tonorth displacement indicated by half-arrows. Thin beds at left contain a minor, faulted kink fold that reflects the opposite sense of shear. This may be a parasitic drag structure generated by the flexural slip-shear couple in the overturned forelimb, directly analogous to the D-2 folds interpreted in fig. 15 from structures on the Ivishak River. 


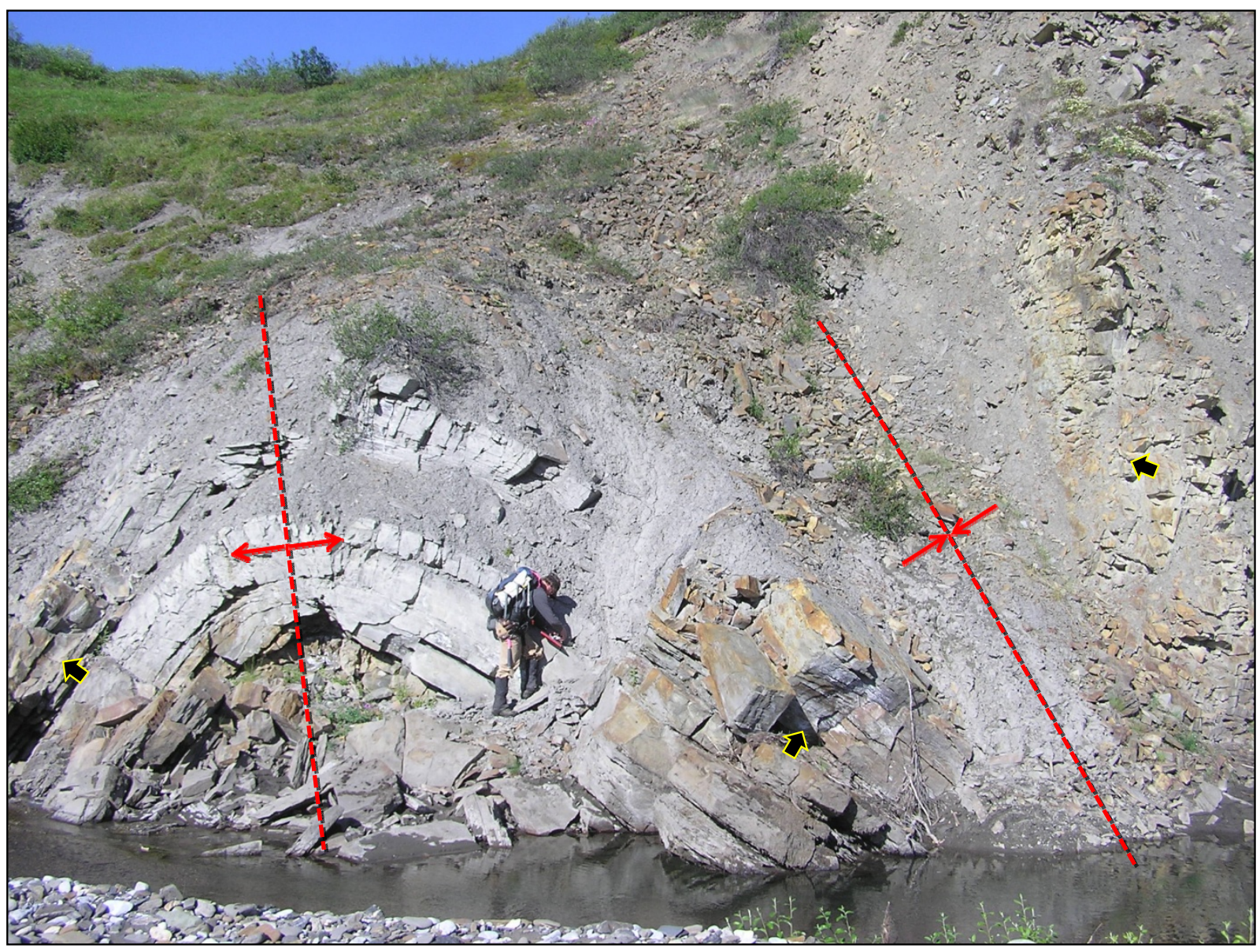

Figure 18. View to west of south-vergent asymmetric, concentric anticline-syncline pair in upright Gilead-like sandstones and mudstones at station 07PD133. Small arrows indicate stratigraphic up direction; red lines and arrows approximate axial traces of folds. This is very near the collection site of the Turonian bivalve Inoceramus labiatus reported by Reifenstuhl (1991), consistent with a possible transitional or interfingering boundary between the upper Gilead sandstone and Turonian strata mapped elsewhere as Seabee Formation. See fig. 3 for location.

margin of the Colville foreland basin. The prominent Cenomanian-Turonian condensed section known from north of the foredeep axis in the Umiat and Tarn-Meltwater areas may be poorly developed or missing in this southern setting nearer the orogenic front, where sediment supply may have been less restricted by sea level rise. Comparison of outcrop stacking architecture with logs from the Lupine Unit 1 well suggest the Gilead sandstone is, at a minimum, a good analogue for interpreting the lower Brookian sequence sandstones of the gas-prone Foothills province in the subsurface. It may, in fact, be highly correlatable in an east-west direction to potential subsurface reservoirs. We remain uncertain as to the range of water depths represented by some of these deposits, and their setting relative to shelf-clinoform, orogenic wedge-top, or ramp models of the basin's southern margin. We have found no compelling evidence of a mid-Cretaceous unconformity hypothesized by Keller and others (1961), but the relationship between the Gilead succession and a much less deformed tuffaceous mudstone of probable Upper Cretaceous age at one location could be explained either by structure or by an angular unconformity, and requires further investigation.

Structural style and the amount of shortening with the Gilead sandstone and adjacent units vary dramatically along strike between the southern traverse segments on the Ivishak River and Gilead syncline. The southern segment of the Ivishak River transect is intensely folded and thrust faulted, dominated by long stretches of vertical to strongly overturned beds separated by short intervals of upright, gently-dipping strata. In contrast, at Gilead syncline, the unit is folded into a broad, upright syncline, probably in the passive roof of an underlying duplex in Jurassic and Triassic units. 
The northern segments of the Ivishak River and Gilead Creek traverses are also complexly shortened by open to tight folds and thrusts, but this structural belt is dominated by south-dipping beds with only local overturning. Much of this northern trend is considered an eastward continuation of the Aufeis anticline, which has been deflected, more severely shortened, and structurally elevated as it approaches the northeastern salient of the Brooks Range. The predominant south dip of beds in this northern belt probably reflects the presence of south-dipping, north-vergent thrusts at depth. Rocks of apparent Gilead affinity, including probable Seabee-equivalent Turonian strata, are internally deformed in this belt and may be thrust over younger Canning Formation along its northern edge on both drainages. Toward the northern end of the Gilead Creek traverse, deformation dies out in moderately to gently northward-dipping Upper Cretaceous sandstones and mudstones of the Canning and Schrader Bluff formations, possibly in the roof of a north-tapering triangle zone.

\section{ACKNOWLEDGMENTS}

In addition to State and Federal funding through the Alaska Division of Geological \& Geophysical Surveys, the Alaska Division of Oil and Gas, and the U.S. Geological Survey, 2007 field studies were supported by energy industry contributors Anadarko Petroleum, BG Alaska E\&P, Chevron, ConocoPhillips, Eni Petroleum, FEX, Petro-Canada, Pioneer Natural Resources, and Shell E\&P. We also thank the numerous geoscientists from these companies who shared their time and technical opinions with us in the field. Outcrop-based discussions with these and other colleagues have helped shape many of the ideas presented here. Finally, the authors thank Bob Swenson for suggesting improvements to the manuscript in his technical review.

\section{REFERENCES}

Bird, K.J., 2001, Alaska; A twenty-first-century petroleum province, in Downey, M.W., Threet, J.C., and Morgan, W.A., eds., Petroleum provinces of the twenty-first century: American Association of Petroleum Geologists Memoir 74, p. 137-165.

Blythe, A.E., Bird, J.M., and Omar, G., 1996, Deformational history of the central Brooks Range, Alaska; Results from fission-track and ${ }^{40} \mathrm{Ar} /{ }^{39} \mathrm{Ar}$ analyses: Tectonics, v. 15, p. 440-455.

Carman, G.J., and Hardwick, P., 1983, Geology and regional setting of Kuparuk oil field, Alaska: American Association of Petroleum Geologists Bulletin v. 67, p. 1,014-1,031.

Decker, J., Camber, W., Vandergon, M.A., and Crowder, R.K., 1988, Arctic Creek facies, Arctic National Wildlife Refuge, northeastern Alaska: American Association of Petroleum Geologists Bulletin, v. 73, p. 176-177.

Decker, P.L., 2007, Brookian sequence stratigraphic correlations, Umiat Field to Milne Point Field, west-central North Slope, Alaska: Alaska Division of Geological \& Geophysical Surveys Preliminary Interpretive Report 2007-2, 19 p., 1 sheet.

Detterman, R.L., Reiser, H.N., Brosgé, W.P., and Dutro, J.T., 1975, Post-Carboniferous stratigraphy, northeastern Alaska: U.S. Geological Survey Professional Paper 886, 46 p.

De Ruig, M.J., and Hubbard, S.M., 2006, Seismic facies and reservoir characteristics of a deep-marine channel belt in the Molasse foreland basin, Puchkirchen Formation, Austria: American Association of Petroleum Geologists Bulletin, v. 90, p. 735-752.

Grantz, A., May, S.D., and Hart, P.E., 1990, Geology of the Arctic continental margin of Alaska, in Grantz, A., Johnson, L., and Sweeney, J.F., eds., The geology of North America, the Arctic Ocean region: Geological Society of America, Boulder, Colorado, v. L, p. 257-287.

Houseknecht, D.W., and Schenk, C.J., 2005, Sedimentology and sequence stratigraphy of the Cretaceous Nanushuk, Seabee, and Tuluvak Formations exposed on Umiat Mountain, north-central Alaska, in Haeussler, P., and Galloway, J.P., eds., Studies by the U.S. Geological Survey in Alaska, 2004: U.S. Geological Survey Professional Paper 1709B, 18 p., 1 plate.

Huffman, A.C., Jr., Ahlbrandt. T.S., Pasternack, I., Stricker, G.D., and Fox, J.E., 1985, Depositional and sedimentologic factors affecting the reservoir potential of the Cretaceous Nanushuk Group, central North Slope, Alaska, in Huffman, A.C., ed., Geology of the Nanushuk Group and related rocks, North Slope, Alaska: U.S. Geological Survey Bulletin 1614, p. 61-74.

Keller, A.S., Morris, R.H., and Detterman, R.L, 1961, Geology of the Shaviovik and Sagavanirktok Rivers Region, Alaska: U.S. Geological Survey Professional Paper 303-D, p. 169-222, 5 plates.

LePain, D.L., and Kirkham, R., 2002, Shoreline to basin transition(?) in Albian-Cenomanian strata east of the Sagavanirktok River, Brooks Range Foothills, Alaska [abs]: Pacific Section, American Association of Petroleum Geologists, and Western Region, Society of Petroleum Engineers Joint Technical Conference Program and Abstracts, p. 87-88. 
LePain, D.L., Kirkham, Russell, Gillis, R.J., and Mongrain, Jacob, 2008, Turonian-Campanian strata east of the Trans-Alaska Pipeline corridor, North Slope foothills, Alaska: Progress during the 2001-02 and 2007 field seasons, in Wartes, M.A., and Decker, P.L., eds, Preliminary results of recent geologic field investigations in the Brooks Range foothills and North Slope, Alaska: Alaska Division of Geological \& Geophysical Surveys Preliminary Interpretive Report 2008-1, p. 85-134.

Meigs, A.J., and Imm, T.A., 1995, Geometry and deformation of a duplex and its roof layer; Observations from the Echooka Anticlinorium, northeastern Brooks Range, Alaska, in Combellick, R.A., and Tannian F., eds., Short notes on Alaska Geology: Alaska Division of Geological \& Geophysical Surveys Professional Report 117, p. 19-31.

Miller, E.L., and Hudson, T.L., 1991, Mid-Cretaceous extensional fragmentation of a Jurassic-Early Cretaceous compressional orogen, Alaska: Tectonics, v. 10, p. 781-796.

Miller, J., 1982, Report on referred fossils: U.S. Geological Survey Alaska Paleontological Database, field locality no. 82AMK-22N, online reference http://AlaskaFossil.org.

Molenaar, C.M., 1983, Depositional relations of Cretaceous and Lower Tertiary rocks, northeastern Alaska: American Association of Petroleum Geologists Bulletin, v. 67, p. 1,066-1,080.

Molenaar, C.M., Bird, K.J., and Collett, T.S., 1986, Regional correlation sections across the North Slope of Alaska: U.S. Geological Survey Miscellaneous Field Studies 1907, 1 sheet.

Molenaar, C.M., Bird, K.J., and Kirk, A.R., 1987, Cretaceous and Tertiary stratigraphy of northeastern Alaska, in Tailleur, I., and Weimer, P., eds., Alaskan North Slope Geology, Bakersfield, California, Pacific Section, Society of Economic Paleontologists and Mineralogists and Alaska Geological Society, v. 1, p. 513-528.

Molenaar, C.M., Kirk, A.R., Magoon, L.B., and Huffman, A.C., 1984, Twenty-two measured sections of Cretaceous-Lower Tertiary rocks, eastern North Slope, Alaska: U.S. Geological Survey Open-file Report 84-695, 21 p., 4 sheets.

Mulder, T., and Syvitski, J.P.M., 1995, Turbidity currents generated at river mouths during exceptional discharges to the world oceans: Journal of Geology, v. 103, p. 285-299.

Mulder, T., Syvitski, J.P.M, Migeon, S., Faugeres, J.C., and Savoye, B., 2003, Marine hyperpycnal flows: initiation, behavior and related deposits; A review: Marine and Petroleum Geology, v. 20, no. 6-8, p. 861-882.

Mull, C.G., and Adams, K.E., 1989, Dalton Highway, Yukon River to Prudhoe Bay, Alaska: Alaska Division of Geological \& Geophysical Surveys Guidebook 7, v. 1, 155 p.

Mull, C.G., and Decker, J., 1993, Organic-rich shale and bentonite in the Arctic Creek unit, Arctic National Wildlife Refuge; Implications for stratigraphic and structural interpretations, in Solie, D.N., and Tannian, F., eds., Short Notes on Alaskan Geology 1993: Alaska Division of Geological \& Geophysical Surveys Professional Report 113, p. 41-49.

Mull, C.G., Houseknecht, D.W., and Bird, K.J., 2003, Revised Cretaceous and Tertiary stratigraphic nomenclature in the Colville Basin, northern Alaska: U.S. Geological Survey Professional Paper 1673, 51 p.

Mutti, E., Tinterri, R., Benevelli, G., di Biase, D., and Cavanna, G., 2003, Deltaic, mixed and turbidite sedimentation of ancient foreland basins: Marine and Petroleum Geology, v. 20, p. 733-755.

Myrow, P.M., Fischer, W., and Goodge, J.W., 2002, Wave-modified turbidites: combined-flow shoreline and shelf deposits, Cambrian, Antarctica: Journal of Sedimentary Research, v. 72, p. 641-656.

O’Sullivan, P.B., 1991, Preliminary results of 25 apatite fission track analyses of samples from the Gilead Creek region, North Slope of Alaska: Alaska Division of Geological \& Geophysical Surveys Public-Data File 91$21 \mathrm{C}, 40 \mathrm{p}$.

1996, Late Mesozoic and Cenozoic thermotectonic evolution of the Colville basin, North Slope, Alaska, in Johnsson, M.J., and Howell, D.G., eds., Thermal evolution of sedimentary basins in Alaska: U.S. Geological Survey Bulletin 2142, p. 45-79.

O’Sullivan, P.B., Green, P.F., Bergman, S.C., Decker, J., Duddy, I.R., Gleadow, A.J.W., and Turner, D.L., 1993, Multiple phases of Tertiary uplift and erosion in the Arctic National Wildlife Refuge, Alaska, revealed by apatite fission track analysis: American Association of Petroleum Geologists Bulletin v. 77, p. 359-385.

Pessel, G.H., Robinson, M.S., Clough, J.G., Imm, T.A., Reifenstuhl, R.R., Ryherd, T.J., Myers, M.D., and Mull, C.G., 1990, Preliminary geologic map of the Gilead Creek area, Sagavanirktok A-2 Quadrangle, Arctic Foothills, Alaska: Alaska Division of Geological \& Geophysical Surveys Public-Data File 90-18, 7 p., 1 sheet.

Petter, A.L., and Steel, R.J., 2006, High-latitude recipe for sand delivery to the deepwater via hyperpycnal flow; A greenhouse example from the Early Eocene, Central Spitsbergen Basin [abs]: American Association of Petroleum Geologists Bulletin, v. 90, Annual Meeting Program Abstracts (http://www.searchanddiscovery. net/documents/2006/06088houston_abs/abstracts/petter.htm). 
Plink-Björklund, P., Steel, R., Clark, B., Pontén, A., and Sjögren, L., 2002, Hyperpycnal flow turbidites as an indicator for sequence boundary in slope turbidite systems of Spitsbergen Central Basin [abs]: American Association of Petroleum Geologists Bulletin, v. 86, Annual Meeting Program Abstracts (http://www.searchanddiscovery. net/documents/abstracts/annual2002/DATA/2002/13ANNUAL/SHORT/43245.pdf).

Reifenstuhl, R.R., 1989, Measured stratigraphic section of the Gilead Creek sandstone, northeastern Alaska, ANWR: Alaska Division of Geological \& Geophysical Surveys Public-Data File 89-26B 16 p., 1 sheet.

1991, Gilead sandstone, northeastern Brooks Range, Alaska: An Albian to Cenomanian marine clastic succession, in Reger, R.D., ed., Short Notes on Alaskan Geology 1991: Alaska Division of Geological \& Geophysical Surveys Professional Report 111, p. 69-76.

Robinson, M.S., Decker, J.E., Clough, J.G., Reifenstuhl, R.R., Bakke, A.A., Dillon, J.T., Combellick, R.A., and Rawlinson, S.E., 1989, Geology of the Sadlerochit and Shublik Mountains, Arctic National Wildlife Refuge, northeastern Alaska: Alaska Division of Geological \& Geophysical Surveys Professional Report 100, 1 sheet, scale $1: 63,360$.

Schenk, C.J., and Bird, K.J., 1993, Depositional sequences in Lower Cretaceous rocks, Atigun syncline and Slope Mountain areas, Alaskan North Slope, in Dusel-Bacon, C., and Till, A.B., eds., Geologic studies in Alaska by the U.S. Geological Survey, 1992: U.S. Geological Survey Bulletin 2068, p. 48-58.

Vogl, J.J., 2002, Late-orogenic backfolding and extension in the Brooks Range collisional orogen, northern Alaska: Journal of Structural Geology, v. 24, p. 1,753-1,776.

Vogl, J.J., Calvert, A.T., and Gans, P.B., 2002, Mechanisms and timing of exhumation of collision-related metamorphic rocks, southern Brooks Range, Alaska; Insights from ${ }^{40} \mathrm{Ar}^{39} \mathrm{Ar}$ thermochronology: Tectonics, v. 21, p. 2-1-2-17.

Wartes, M.A., Loveland, A.M., Wallace, W.K., Gillis, R., Peapples, P.R., Reifenstuhl, R.R., and Mull, C.G., 2007, Geology of the Kavik River area, east-central North Slope, Alaska; Preliminary Results of the 2006 STATEMAP project [abs.]: Alaska Geological Society Annual Technical Conference Abstracts.

Whittington, C.L., 1956, Revised stratigraphic nomenclature of Colville Group, in Gryc, G., and others, Mesozoic sequence in Colville River region, northern Alaska: American Association of Petroleum Geologists Bulletin v. 40, p. 244-253.

Worden, R.H., and Burley, S.D., 2003, Introduction, in Burley, S.D., and Worden, R.H., eds., Sandstone diagenesis; Ancient and recent: Malden, Massachusetts, Blackwell Publishing, 649 p. 
This page has intentionally been left blank. 